\title{
Potential Environmental Impacts of Quarrying Stone in Karst- A Literature Review
}
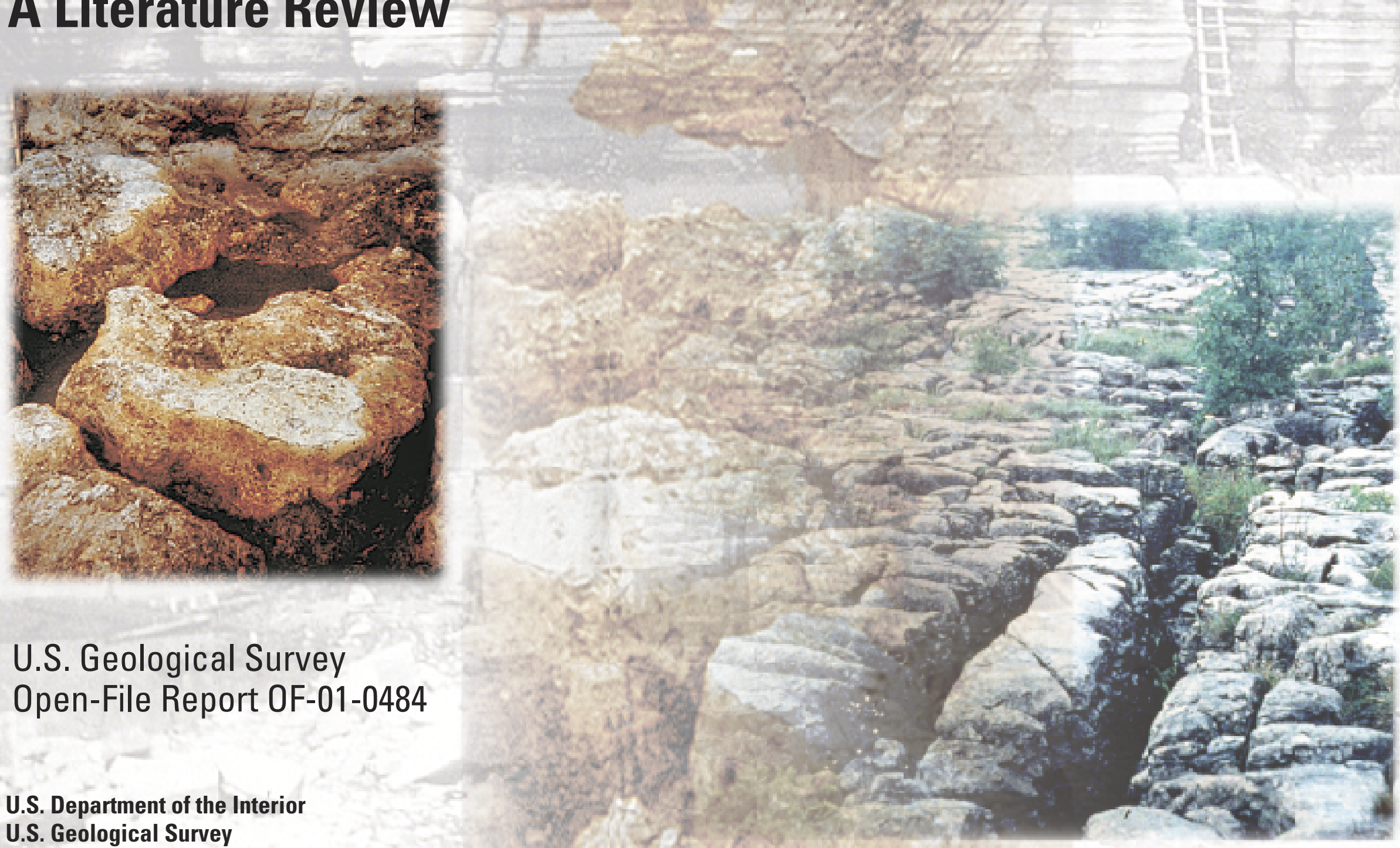

U.S. Department of the Interior

U.S. Geological Survey

U.S. Geological Survey

Open-File Report OF-01-0484 
Potential Environmental Impacts of Quarying Stone in Karst-

\section{A Literature Review}

By WilliamH. Langer

Open-File Report OF-O1-O484

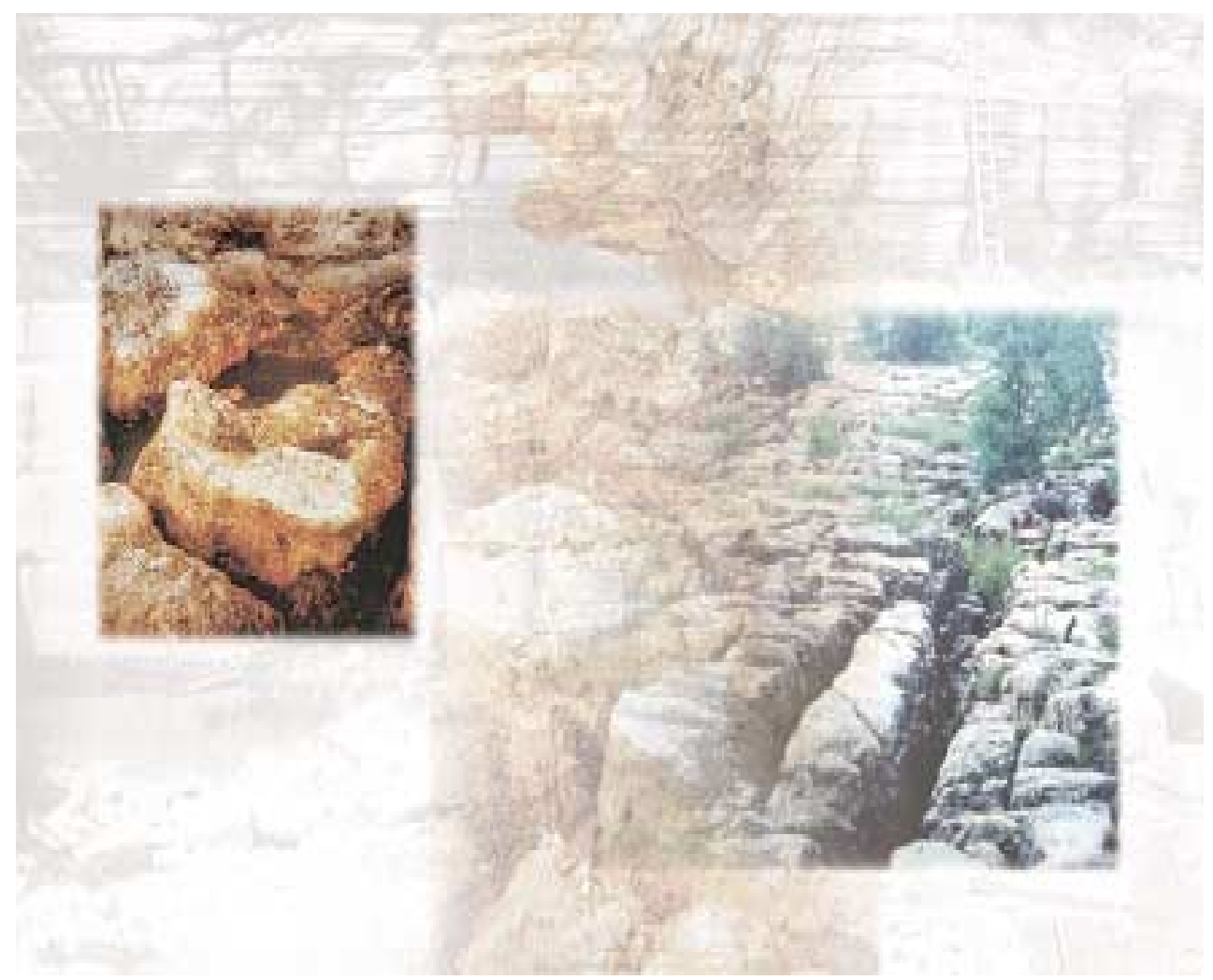

2001

This report is preliminary and has not been reviewed for conformity with U.S. Geological Survey (USGS) editorial standards nor with the North American Stratigraphic Code. Any use of trade, product, or firmnames is for descriptive purposes only and does not imply endorsement by the USGS.

U.S. Department of the Interior

U.S. Geological Survey 
U.S. Department of the Interior

Gale A. Norton, Secretary

U.S. Geological Sunvy

Charles G. Groat, Director

Version 102002

This publication is only available online at: hthx//geology.cr.usgs.gov/pub/ofirs/OrR-01-0484

Any use of trade, product, or fimnames in this puldication

is for descriptive purposes only and does not

imply endorsement by the U.S. Govermment

Layout and cover design by Carol Quesenberry 


\section{Contents}

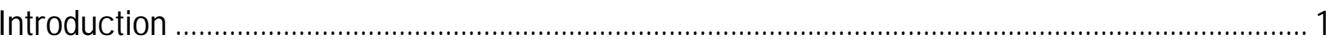

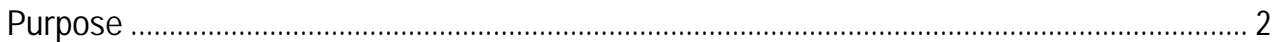

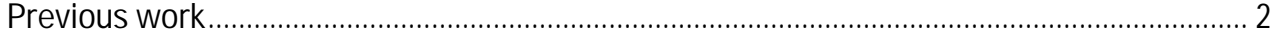

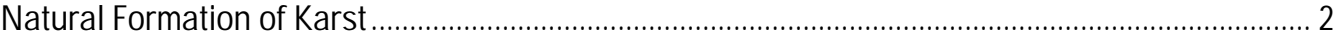

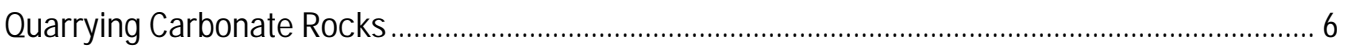

Production and Use of Carbonate Rocks...................................................................................... 7

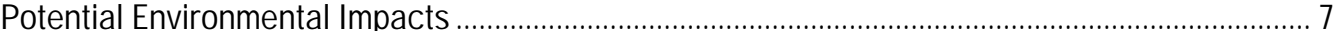

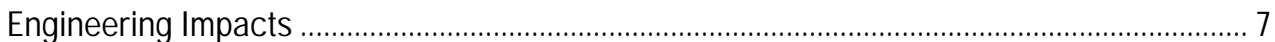

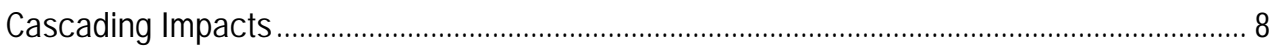

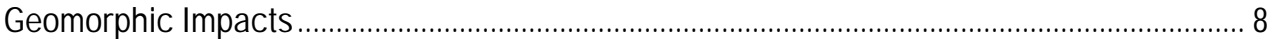

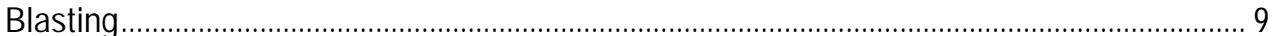

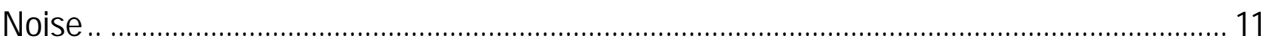

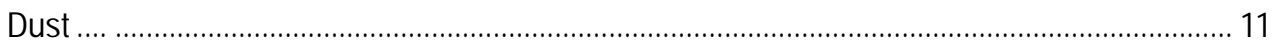

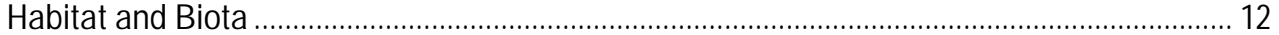

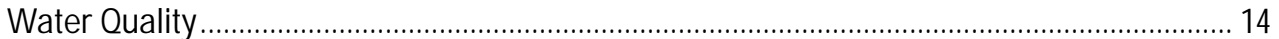

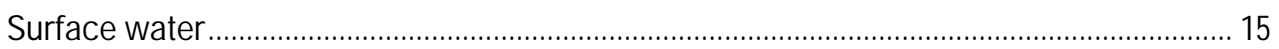

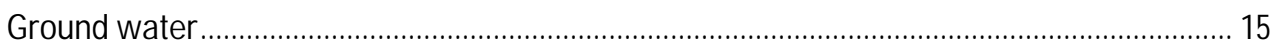

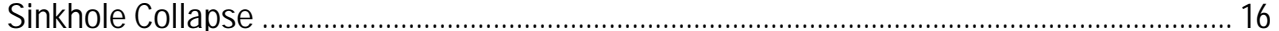

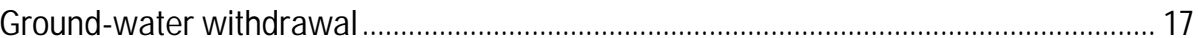

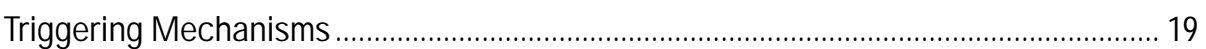

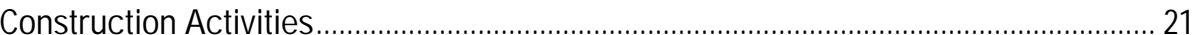

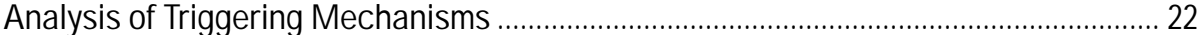

Sinkhole Size, Occurrence, and Area Impacted ............................................................ 2Z

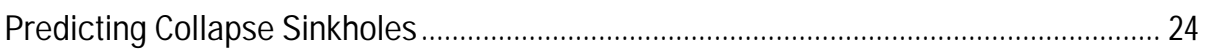

Reclamation .

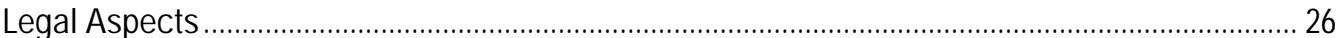

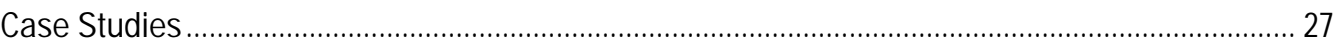

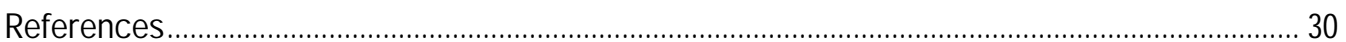




\section{Figures}

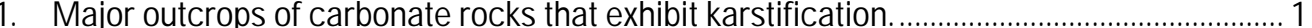

2. Summary of effects and impacts of various human activities on karst terrains .................... 2

3. Typical shallow sinkhole in karst terrain of Cherokee County, Kansas .................................. 4

4. Weathered outcrop and smooth working face of dimension stone quarry.............................. 4

5. Cave opening in karst terrain, Škocjan Cave, Slovenia ........................................................... 5

6. Irregular surfaces on karst bedrock ...................................................................................... 5

7. Working face of dimension stone limestone quarry in Lawrence County, Indiana.................. 6

8. Working face of crushed stone operation showing rubble created by blasting ..................... 7

9. “Resource snake" graph showing relative values of non-fuel

mineral resource production .................................................................................. 8

10. Engineering techniques to mitigate impacts of noise and dust................................................ 9

11 Quarries can occupy a significant part of the visual landscape ............................................ 9

12 Rock is drilled and blasted for use as crushed stone

13. Noisy equipment can be located away frompopulated areas and enclosed in sound-deadening structures

14. Dust control techniques include the use of water trucks and sweepers

on haul roads

15.

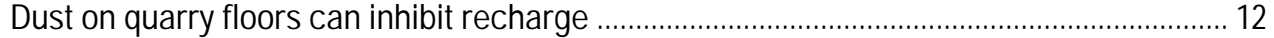

16

Karst inhabitants

17. Fuel oil spills can rapidly contaminate karst...

18. Natural sinkhole near Ste. Genevieve, Missouri

Human-induced sinkholes formed during the development of an irrigation well affected a 20-acre area.

20. Block diagramshowing sinkhole development.

21 Diagramshowing mechanics of sinkhole development

A giant sinkhole at a drilling site swallowed a well-drilling rig, a water truck, and a trailer loaded with pipe

23. The "December giant," a large sinkhole, developed rapidly in Shelby County, Alabama, in December 1972

24. Face of limestone quarry after restoration blasting and habitat reclamation 


\section{Potential Environmental Impacts of Quarying Stone in Karst-}

\section{A Lterahre Review}

\section{By WilliamH. Langer}

\section{Introchuction}

Limestone, dolomite, and marble the carbonate rocks - are the principal karst-forming rocks. Karst is a type of topography that is formed on limestone, gypsum, and other rocks by dissolution that is characterized by sinkholes, caves, and underground drainage regions. Karst areas constitute about 10 percent of the land surface of the world (fig. 1) (Drew, 1999), and there is widespread concern for the effects that human activities have upon the karst environment. Much of the concern is motivated by the adverse environmental impacts of previous human activities in karst areas and the effects that those impacts have had on the quality of life. Many human activities can negatively impact karst areas, including deforestation, agricultural practices, urbanization, tourism, military activities, water exploitation, mining, and quarrying (Drew, 1999) (fig. 2).
Minerals associated with karst have been exploited for many years. Some carbonate rocks contain valuable supplies of water, oil, and gas, may weather to form bauxite deposits, and are associated with manganese and phosphate rock (guano). Coal is often found within thick carbonate rock sequences. Like other rocks, karst rocks may host ore deposits containing lead, zinc, iron, and gold.

Much of the resource extraction conducted in areas of karst is for the rock itself. Unweathered carbonate rocks provide crushed stone and dimension stone resources. The term "crushed stone" refers to the product resulting from the crushing of rocks such that substantially all faces are created by the crushing operation (ASTM, 2000). The term "dimension stone" is generally applied to masses of stone, either naturally occurring or prepared for use in the form of blocks of specified shapes and sizes, that may or may not have one or more mechanically dressed surface (Bowles, 1939: ASTM, 1998).

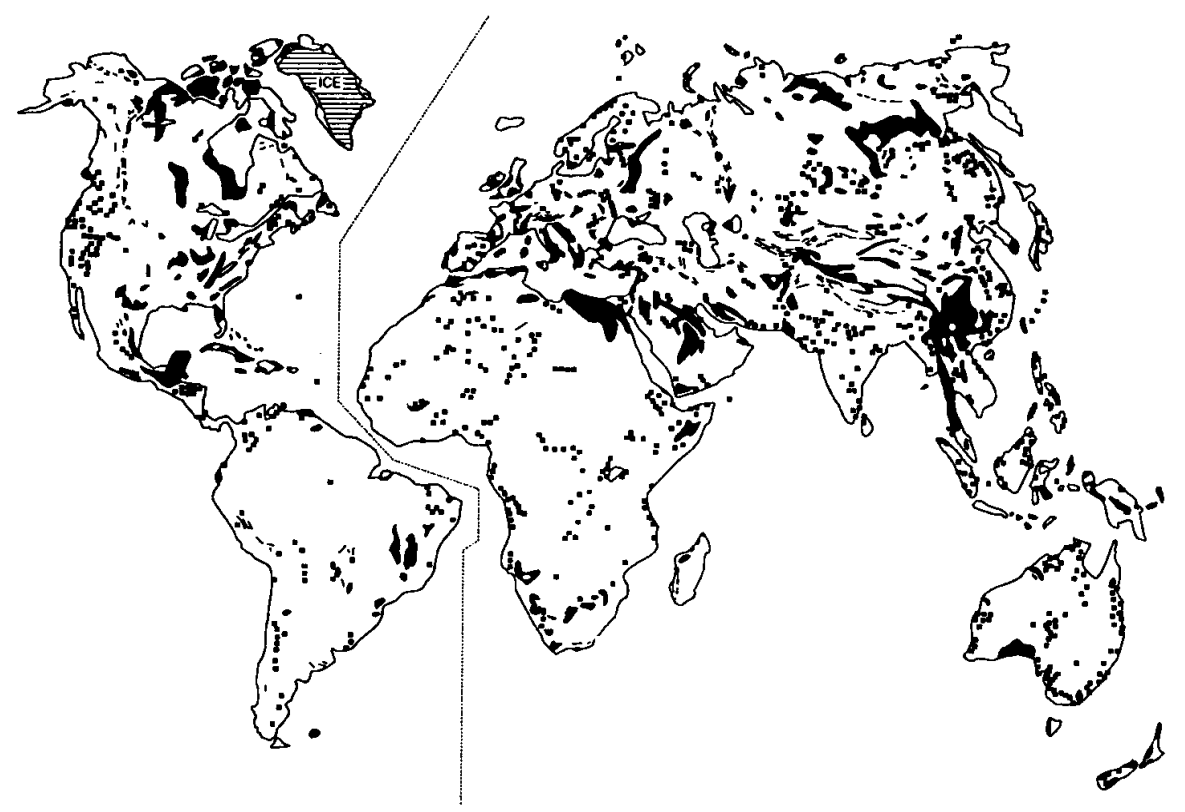

Figure 1 Major worldwide outcrops of carbonate rocks that exhibit at least some karstification (after Ford and Williams, 1989). 


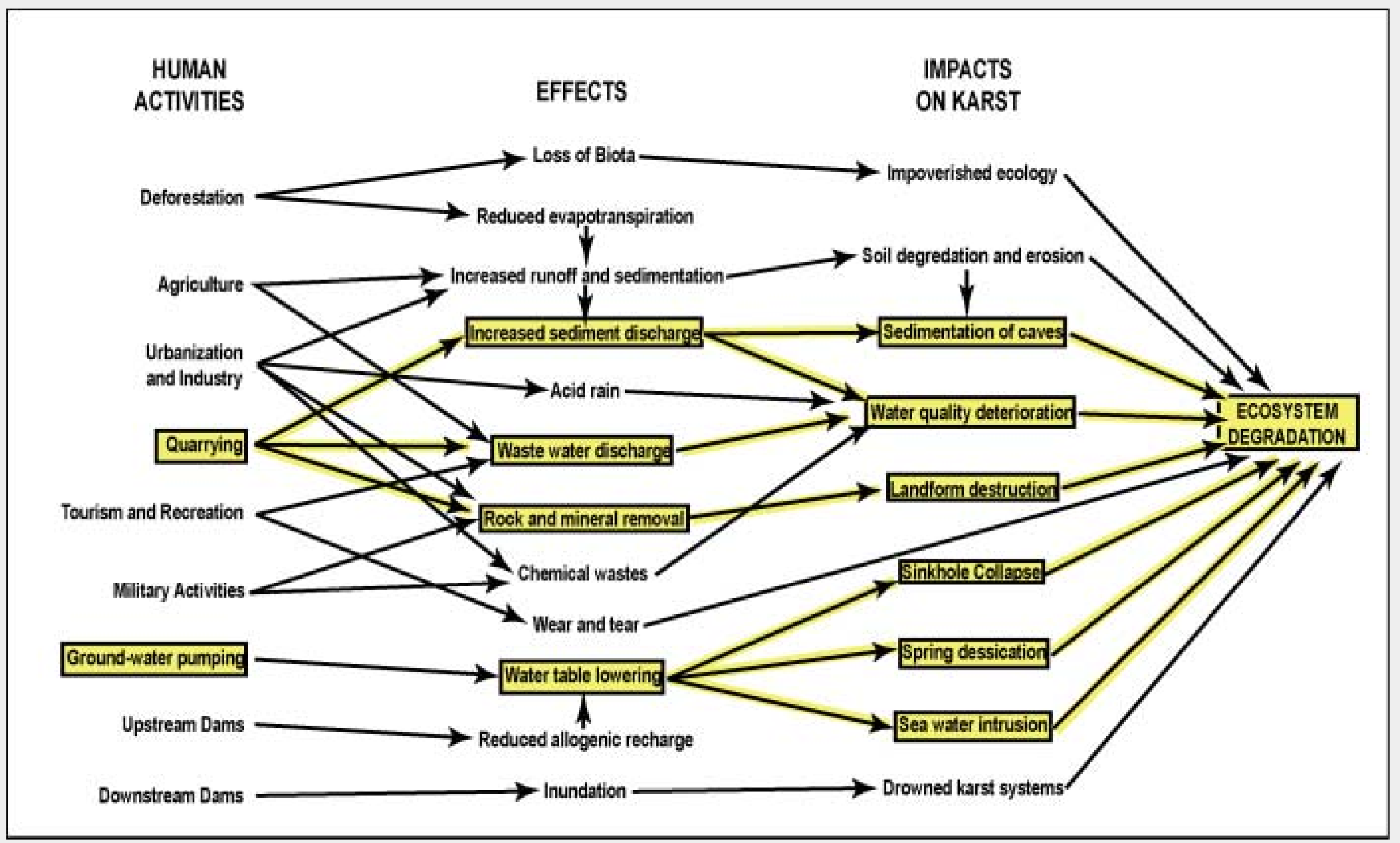

Figure 2 Summary of effects and impacts of various human activities on karst terrains. Effects and impacts fromquarrying are highlighted in yellow. (Modified fromWilliams, 1993a.) 
Carbonate rocks provide dimension stone, aggregate resources, and raw materials for cement and other industrial and agricultural uses. Over 70 percent of crushed stone produced in the United States is made from carbonate rock. The products derived from carbonate rocks provide essential materials for society -materials that we need to maintain our current standard of living. Quarrying ${ }^{1}$ carbonate rocks for use as crushed stone and dimension stone can be accomplished with no significant impacts to the environment, if done carefully and within the limits set by nature. However, if proper precautions are not taken many human activities in karst, including extraction of carbonate rocks, can result in damage to the environment and associated increases in costs for environmental compliance or liability.

\section{Punpose}

This report describes the state-ofthe-knowledge regarding the environmental impacts from quarrying carbonate rocks in karst. Documentation of the relationships between carbonate rock quarries and environmental problems in karst has existed for nearly fifty years, but is scarce. There are numerous articles in the literature that describe environmental impacts on karst from human activities other than quarrying, but there are relatively few articles that specifically refer to impacts from quarrying.

In this report, the term "quarrying" applies to both surface quarries and underground mines from which cabonate rocks are extracted.
The reported environmental impacts have occurred in a wide variety of karst terrains, under a wide variety of climatic conditions, where the natural systems have been stressed by a wide variety of human activities. It should not be assumed that impacts in one karst terrain under a particular set of natural and manmade conditions will also happen in a different karst terrain with a different set of natural and man-made conditions.

\section{Previous work}

In recent years numerous publications have addressed issues related to karst in general, as well as issues specifically related to human impacts on karst. Publications addressing human impacts on karst include a special supplement of the journal Catena entitled Karst Terraines: Environmental Changes and Human Impact (Williams, 1993); a special issue of Environmental Geology with the theme of addressing Environmental Change in Karst Areas (Ford, 1993); a special issue of Engineering Geology with the theme Sinkholes and the Engineering and Environmental Impacts of Karst (Beck, 1999), and the publication Karst Hydrogeology and Human Activities (Drew and Hötzl, 1999). The Florida Sinkholes Research Institute has held symposiums concerned with sinkholes in karst at approximately two-year intervals (Beck, 1984, 1989 1993; Beck and Pearson, 1995; Beck and Stephenson, 1997; Beck and Wilson,
1987; Beck and others, 1999). The American Geological Institute Environmental Awareness Series 4, Living With Karst, is a non-technical discussion of environmental issues in karst (Veni and DuChene, 2001). Few of the reports in the publications listed above are primarily concerned with quarrying in karst; however, those publications do illustrate the complexities of cause and effects of human activities in karst.

Although a relationship between environmental damage and quarrying of carbonate rock has been well documented for over fifty years (Foose, 1953), there are only a few reports that include major discussions of the environmental impacts of quarrying in karst. These reports include Development of Sinkholes Resulting from Man's Activities in the Eastern United States (Newton, 1987), Ground Subsidence, which includes a chapter Sinkholes on Limestones (Waltham, 1989), and Karst Hydrogeology and Human Activities (Drew and Hötzl, 1999), which includes a chapter on Extractive Industries Impact (Hess and Slattery, 1999). There are a few individual reports scattered through the literature that address the environmental impacts of quarrying carbonate rocks in karst. In addition, there are reports that describe environmental impacts on karst from mining resources other than carbonate rock. Theories about how extraction of carbonate rock can impact the environment can be extrapolated from some of these reports.

\section{Nahural Fommiton}

\section{of Karst}

There is a tremendous variety of carbonate rocks and these rocks exist in a broad range of climatic situations. Weathering of carbonate rocks produces diverse types of karst landscapes (fig. 3), far too many types to be described here. Instead, this report gives a simplified description of the karst forming processes. Readers interested in learning the details of karst formation are encouraged to consult the numerous textbooks and research reports that describe the geohydrologic and geomorphic processes involved with karst development. For example, Karst Geomorphology (Sweeting, 1981) contains benchmark papers about karst, including excerpts from Das Karstphänomen (Cvijíc, 1893). Process geomorphology (Ritter and others, 1995), a recent textbook, discusses karst from a process / response perspective.

Karst Geomorphology (Jennings, 1985) is a technical description of karst written for the non-scientific audience. Karst Lands (White and others, 1995) is a concise article in American Scientist that describes karst formation and hydrology. Sinkholes in Pennsylvania (Kochanov, 1999) is a non-technical description of karst prepared for non-scientific audiences. The International Geographical Union Commission on Sustainable Development and Management of Karst Terrains published eight annotated bibliographies of karst research studies (for example, Urushibara-Yoshino, 2000). 
Natural karst processes occur gradually over hundreds to thousands of years. The formation of karst includes interactions between carbonate rocks and slightly acidic water. (Actually karst can form on other soluble rocks such as gypsum; however, this report is restricted to carbonate rocks.) Carbonic acid is a mild acid formed when rainwater and carbon dioxide react. As the rainwater passes through the soil, the water absorbs more carbon dioxide and becomes more acidic. Carbonate rock contains openings between beds of rock and as fractures or joints created when the rocks were uplifted, uncovered, faulted, or folded (fig. 4). The slightly acidic water percolates into the rocks through these openings. The openings are enlarged by solvent action of acidic water. The dissolution process is selfaccelerating: openings that are enlarged first will transmit more water, thus increasing the rate that acid is brought into contact with the rock, resulting in additional enlargement of the openings.

As underground flow paths controlled by joints, fractures, and bedding planes continue to enlarge over time, water movement changes from small volumes through many small, scattered openings in the rock to concentrated flow through a few well-developed conduits. As flow paths continue to enlarge, caves, conduits, and sinkholes may be formed (fig. 5). Surface streams may lose water to the subsurface or flow into cave entrances, only to reappear many miles away.

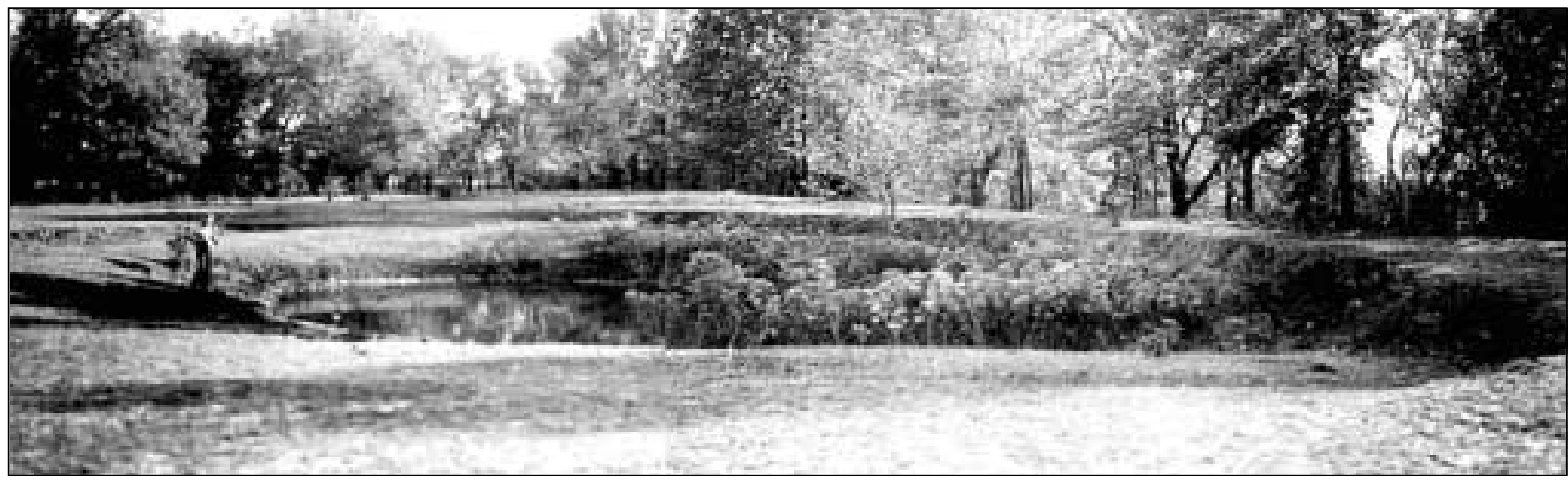

Figure 3 Shallow sinkhole typical of karst terrain in Cherokee County, Kansas. (USGS photographic library- Pierce \#339, 340.)

Unusual bedrock surfaces may be created as the carbonate rock is dissolved (fig. 6a and 6b). In temperate climates, some of the surfaces resemble abstract sculptures or contain pointed columns called pinnacles. A residual soil forms over the bedrock because there are minerals within limestone that are not affected by carbonic acid. As the process of dissolution continues, these insoluble minerals collect on top of the bedrock surface as clayey residual material. Some residual material is carried by water into openings in bedrock where they clog the openings. Other material, such as stream alluvium, may overly the clay. Depending on the climate, topography, and type of parent bedrock, soil on the bedrock surface can be non-existent or greater than $50 \mathrm{~m}$ thick.

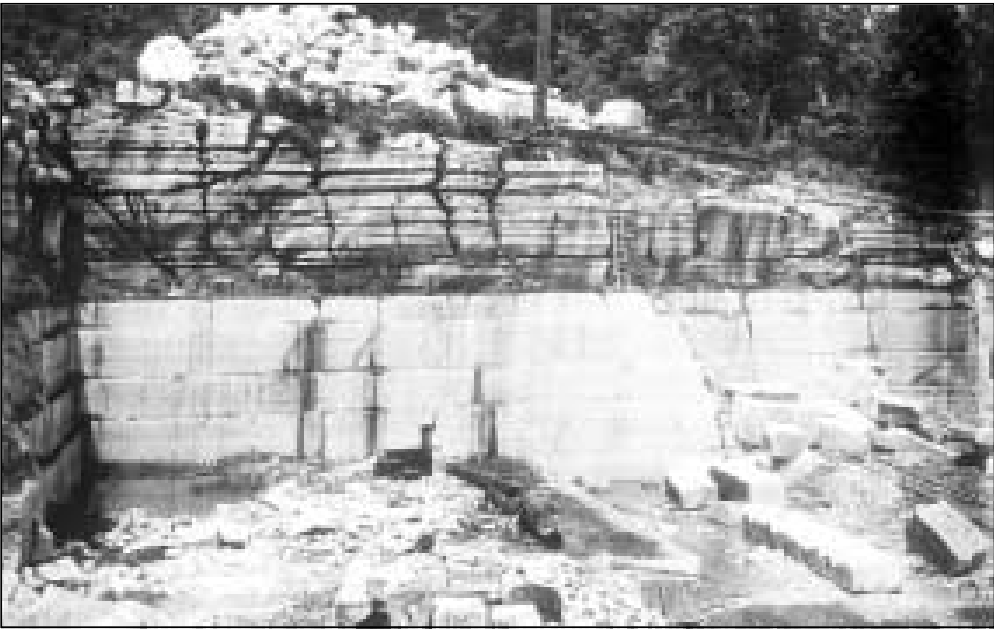

Figure 4 Dimension stone quarry showing weathered outcrop (top) and smooth working face of quarry. Vertical solution channels following fractures and joints in the weathered outcrop extend down into the smooth working face. Horizontal solution features occur between beds of the rock. Notice ladder for scale. (USGS photographic library- Loughlin 154.) 

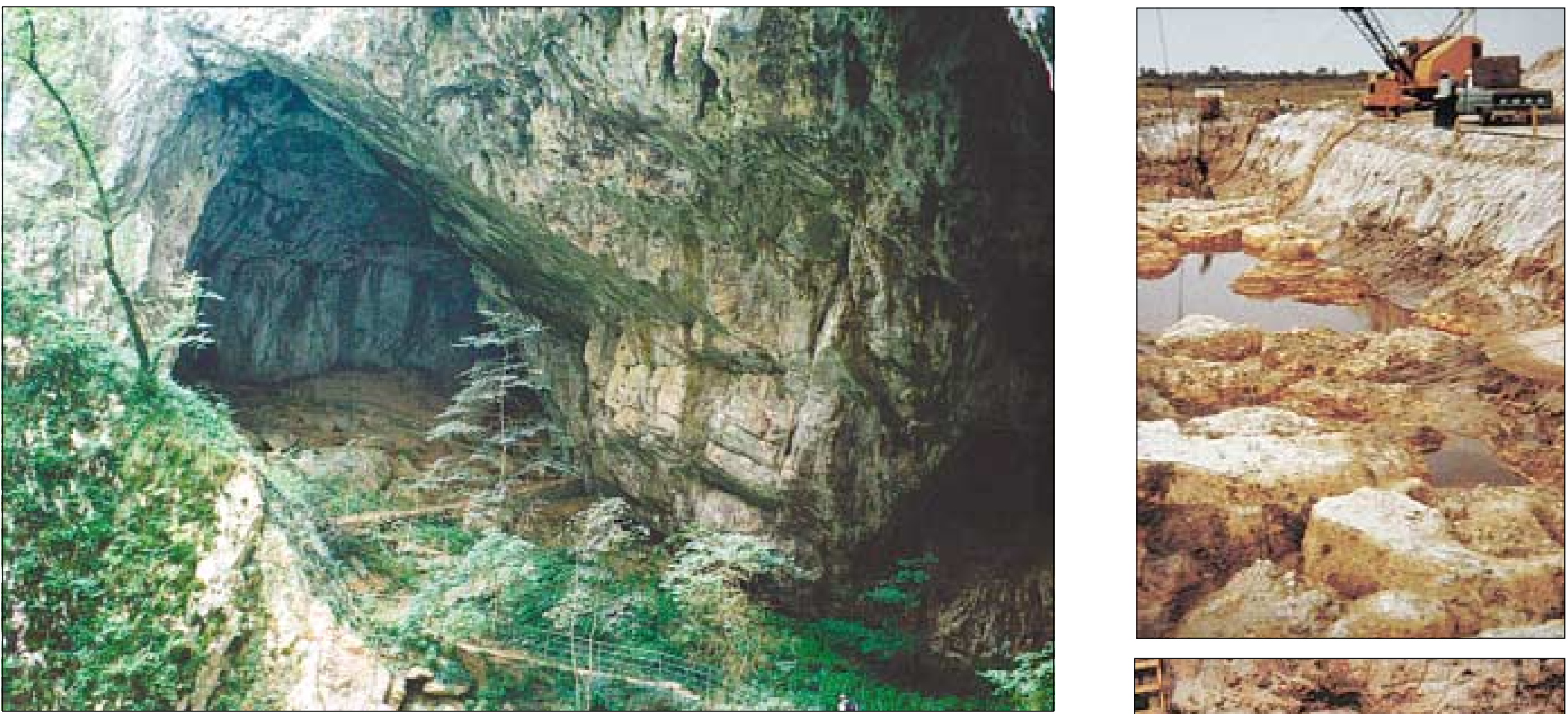

Figure 5 (above). Cave opening in karst terrain, Škocjan Cave, Slovenia.

Figure 6-a (right). Limestone surface in karst area with no soil cover.

Figure 6-b (far right, top and bottom). Removal of overburden has exposed the furrowed and pitted surface of carbonate rock. (Photograph courtesy of Keith Bennett, Williams Earth Sciences, Inc.)

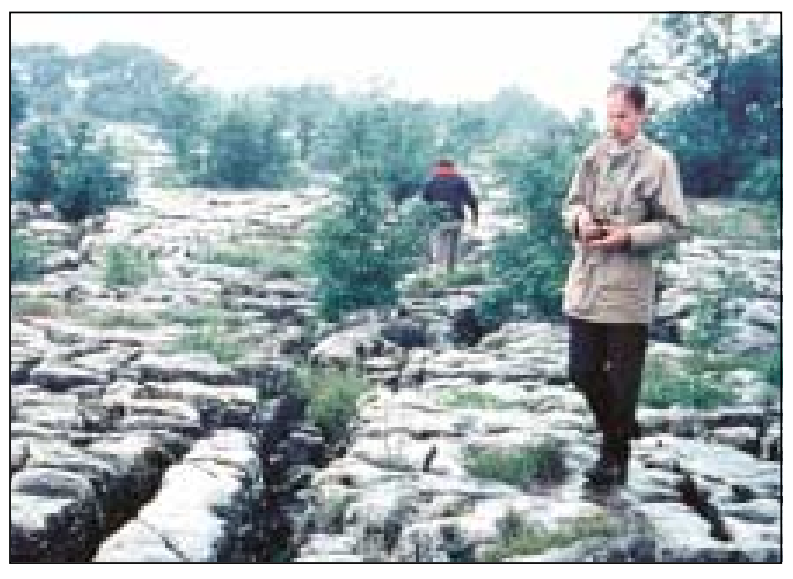

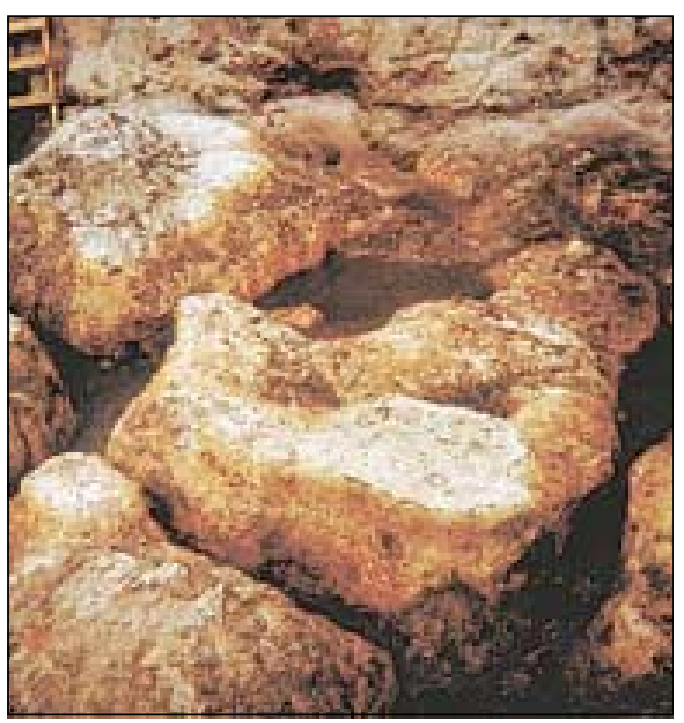




\section{Quarying}

\section{Carbonate Rocks}

The general objective of dimensionstone quarrying is to produce large rectangular blocks suitable for cutting into smaller, regularly-shaped products. The quarrying operation cuts a block of stone free from the bedrock mass by first separating the block on all four vertical sides and then undercutting or breaking the block away from the bedrock (fig.

7). Two of the oldest methods for quarrying are channel cutting and drilling and broaching. A channeling machine cuts a channel in the rock using multiple chiseledged cutting bars that cut with a chopping action. In drilling and broaching, a drilling tool first drills numerous holes in an aligned pattern. The broaching too then chisels and chops the web between the drill holes, freeing the block. Both channel cutting and drilling and broaching are slow and the cutting tool requires frequent sharpening. Both methods have generally been replaced with other more efficient methods.
Line drilling and sawing are more modern techniques for quarrying. Line drilling (also called slot drilling) consists of drilling a series of overlapping holes using a drill that is mounted on a quarry bar or frame that aligns the holes and holds the drill in position. Sawing can be accomplished with a variety of saws including wire saws, belt saws, and chain saws. The introduction of syntheticdiamond tools during the 1960's revolutionized stone working. A variety of explosive techniques may also be used to quarry dimension stone, but explosives generally are used in very small amounts, if at all, to avoid fracturing the stone block.

The general objective of crushed stone quarrying is to produce relatively small pieces of rock that are suitable for crushing into gravel-sized particles (fig. 8). To produce crushed stone, the rock is first drilled and blasted. Blasting commonly breaks the rock into pieces suitable for crushing. When the blasted material is dry, it can be extracted by using conventional earth-moving equipment, such as bulldozers, front loaders, track hoes, and scraper graders. Rock quarries that do not penetrate the water table, or where discharge from the water table naturally drains from the quarry, is offset by evaporation, or is otherwise insignificant, commonly are mined dry.

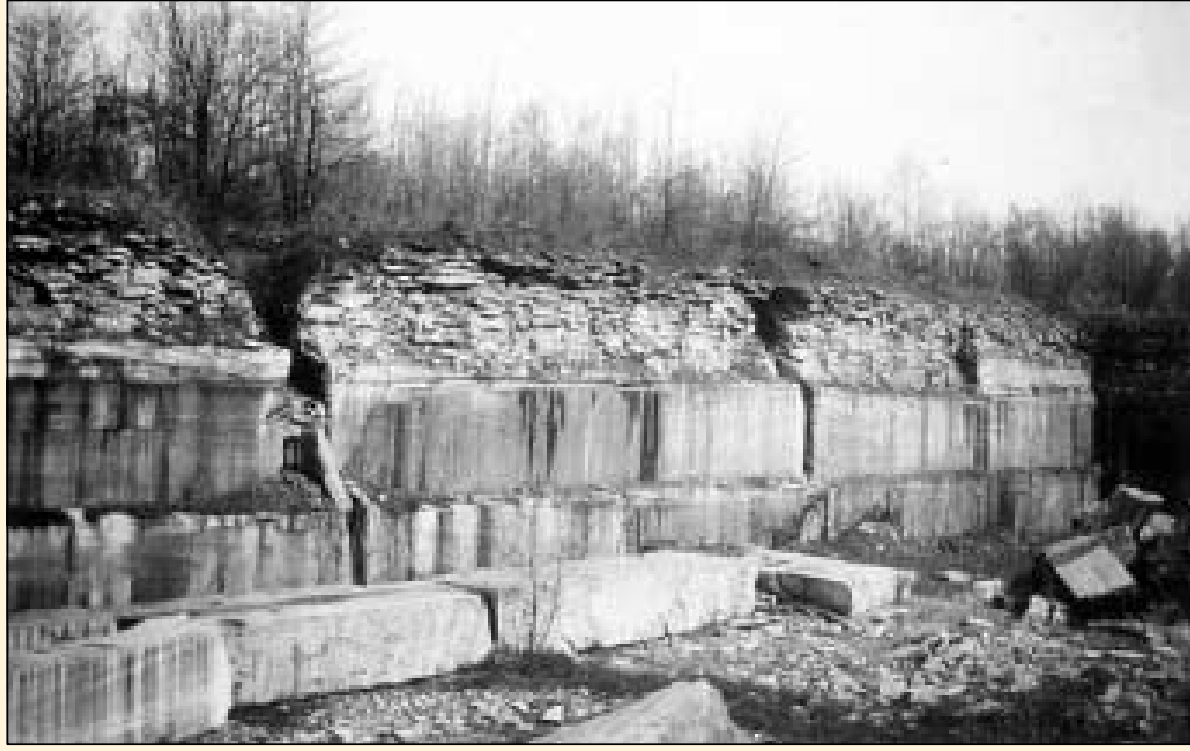

Figure 7. Working face of dimension stone limestone quarry in Lawrence County, Indiana, showing smooth surfaces fromwhich large blocks have been removed. (USGS photographic library - Burchard \#556.)

Where rock quarries penetrate the water table, the quarries commonly are dewatered by collection and pumping of the ground water. The rock is then mined by the procedures used in a dry quarry. Some operators may prefer not to dewater the quarry, or the inflow may be too great to be pumped. In those operations, the quarries are allowed to fill with water. The rock is drilled and blasted, and the rubble is extracted from under the water using draglines, clamshells, or other equipment. The aggregate may be processed wet or may be placed in windrows and allowed to dry before processing.
Carbonate rock is extracted from about 100 underground mines in the United States. Most of these mines are located in the Mid-Continent and produce crushed stone. 


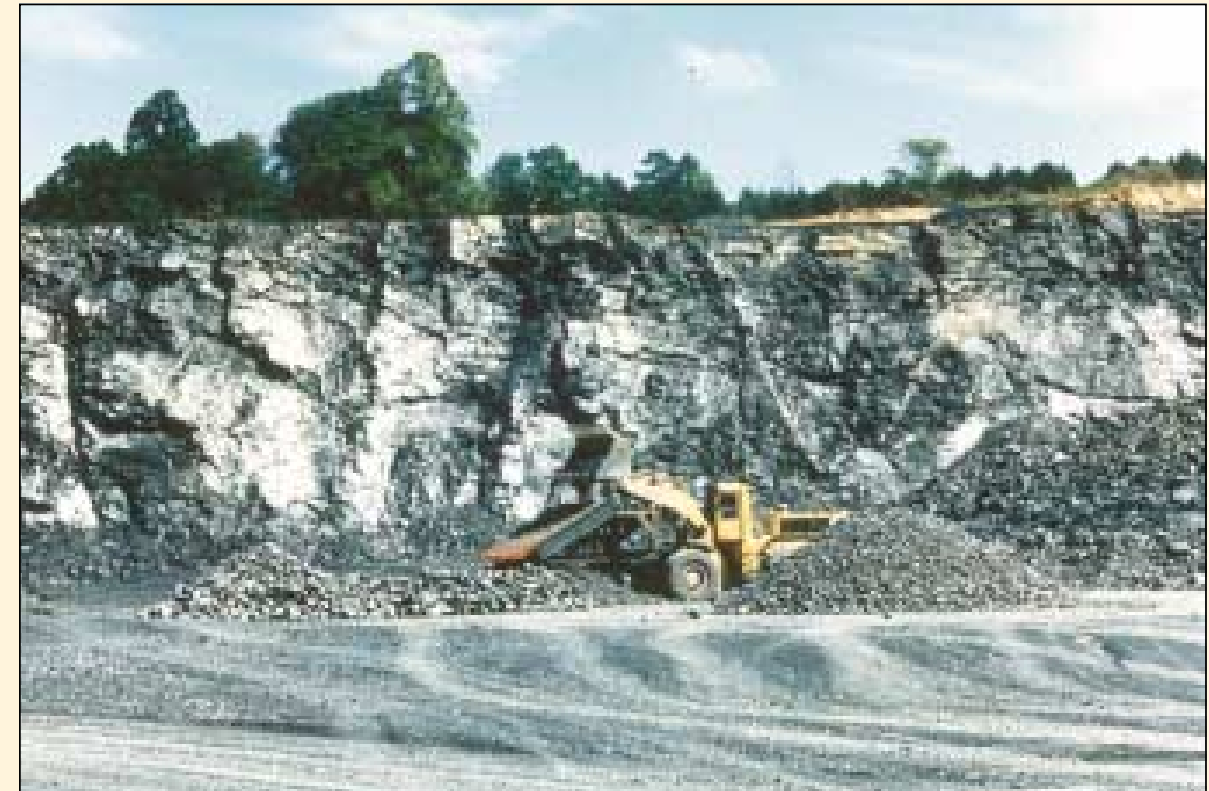

Figure 8 Working face of crushed stone operation showing rubble created by blasting. (Photograph courtesy Luck Stone.)

\section{Production and Use of}

\section{Carbonate Rocks}

Worldwide production of carbonate rocks ranks third in terms of volume and fourth in terms of value for all non-fuel mineral commodities (fig. 9) (Lüttig, 1994). Over 70 percent of the crushed stone produced in the United States comes from carbonate rock, and about three fourths of that is consumed by the construction industry. Crushed carbonate rock also has numerous agriculture and industrial uses. Agricultural uses include fertilizers and insecticides. Industrial uses include the manufacture of cement, pharmaceuticals, processed
Dimension stone has a large number of uses ranging from rustic walls and roughly-shaped paving stones to highly polished floor tile, counter tops, and building facades. The final use of the stone, as well as the methods to quarry and mill the stone, depend on the properties of the source rock. Today, stone is considered by many to be the premier building material and is experiencing resurgence in use for commercial and residential construction. During 1999, dimension limestone or dolomite were extracted from 33 quarries in 10 States. Production was 446,000 metric tons valued at $\$ 74.9$ million. The top five producing states, in descending order by tonnage, were Indiana, Wisconsin, Texas, Minnesota, and Kansas. Other states producing dimension limestone or dolomite include Alabama, Arkansas, California, Ohio, and Vermont. Marble was extracted from 11 quarries in 5 states. Production was 40,300 metric tons valued at $\$ 9.5$ million. Vermont was the leading producing State, followed by Tennessee, Georgia, Colorado, and Arkansas (Dolley, 1999). aper, rubber, leather, synthetic fic glue, ink, crayons, shoe polish, cosmetics, chewing gum, toothpaste, and antacids. During 1999, over one billion tons of crushed limestone, dolomite, and marble valued at over $\$ 5.5$ billion were produced from about 2,200 quarries operating in 48 states. The top 10 states (in decreasing order of production) each produced over 45 millions tons of crushed carbonate rocks - Texas, Florida, Illinois, Ohio, Missouri, Pennsylvania, Tennessee, Kentucky, Indiana, and Alabama (Tepordei, 1999). All of these states contain areas of karst.

\section{Polential}

\section{Environnental Impacts}

Modern technology and scientific investigation methods have made it possible to reduce environmental impacts associated with extraction of carbonate rocks and manage impacts at acceptable levels that do not cause significant harm to the environment. Nevertheless, carbonate rock resources cannot be obtained from the landscape without causing some environmental impacts.

\section{Engineering Impacts}

Some of the environmental disturbance created by quarrying is caused directly by engineering activities during aggregate extraction and processing. The most obvious engineering impact of quarrying is a change in geomorphology and conversion of land use, with the associated change in visual scene. This major impact may be accompanied by loss of habitat, noise, dust, vibrations, chemical spills, erosion, sedimentation, and dereliction of the mined site. Some of the impacts are short-lived and most are easy to predict and easy to observe. Most engineering impacts can be controlled, mitigated, kept at tolerable levels, and restricted to the immediate vicinity of the aggregate operation by employing responsible operational practices that use available engineering techniques and technology (fig. 10). Some reports that generally describe engineering impacts include Barksdale (1991), Kelk (1992), Smith and Collis (2001), Lüttig (1994), Bobrowsky (1998), Primel and Tourenq, (2000) and Langer (2001). 


\section{Cascading Impacts}

In karst environments, aggregate mining may alter sensitive parts of the natural system at or near the site thus creating cascading environmental impacts (Langer and Kolm, 2001). Cascading impacts are initiated by an engineering activity, such as the removal of rock, which alters the natural system. The natural system responds, which causes another impact, which causes ye another response by the system, and on and on. For example, aggregate mining in some karst might lower the water table, which will remove the buoyant support of rock that overlies water-filled caverns or other solution features, which might result in land collapse, which will create a sinkhole. Cascading impacts may be severe and affect areas well beyond the limits of the aggregate operation. Cascading impacts may manifest themselves some time after mining activities have begun and continue well after mining has ceased. Many of the impacts described below are cascading impacts.

\section{Geomonphic Impacts}

Quarrying has an associated, often dramatic, visual impact. Karst terrain is commonly considered to be of high scenic value, thus compounding the effects of visual impacts of quarrying. The principal geomorphic impact of quarrying is the removal of stone, which results in the destruction of habitat including relict and active caves and natural sinkholes (Gunn and Gagen, 1987).

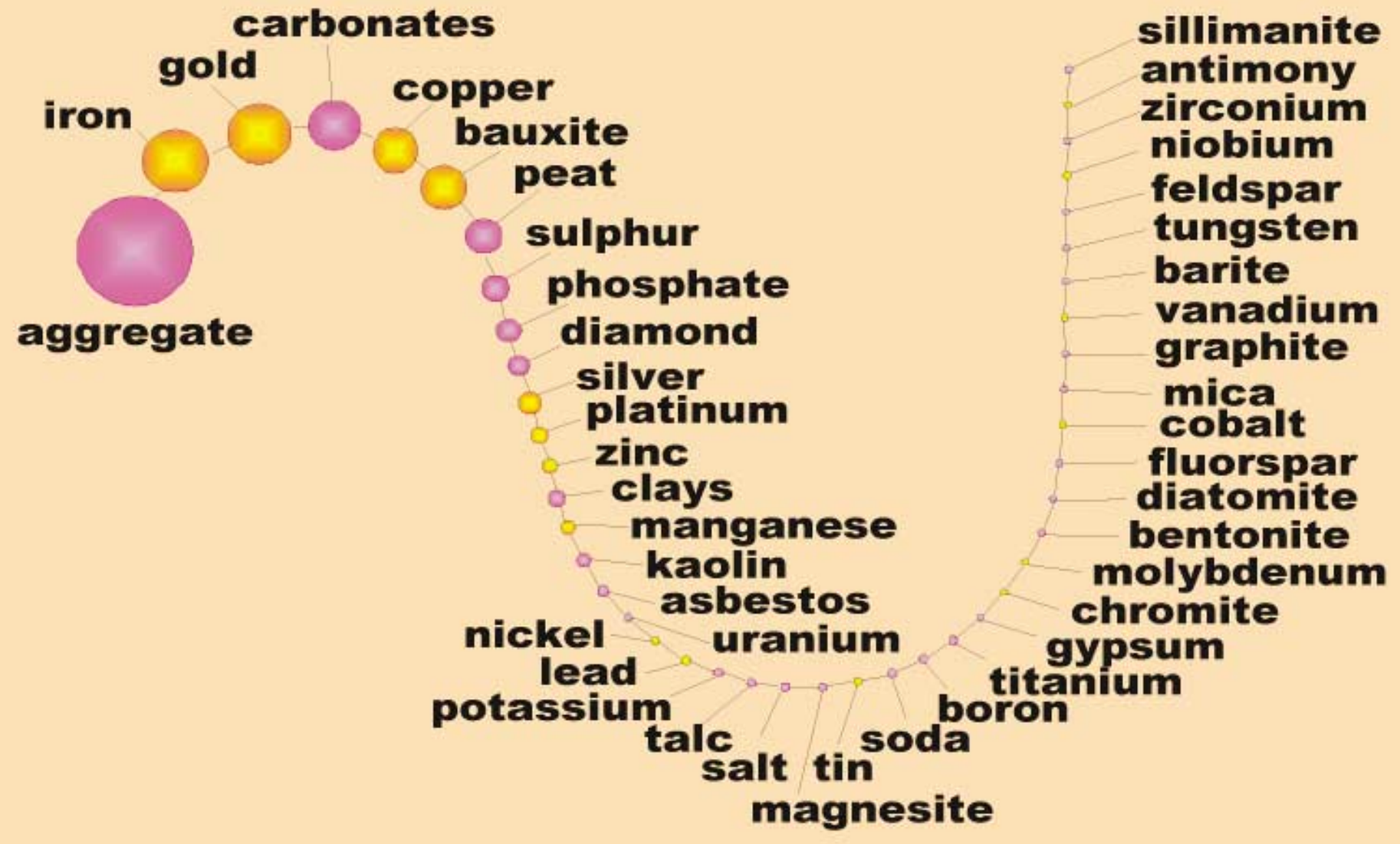

Figure9 "Resource snake" graph showing relative values of non-fuel mineral resource production (fromLüttig, 1994).

The extent of the geomorphic impact is a function of the size of the quarry, the number of quarries, and the location of the quarry, especially with respect to the overall landscape and the local landforms (fig. 11). The influence of quarry size on environmental impact is obvious: all other things being equal, the larger the quarry, the larger the geomorphic impact. The size of quarries has increased over time, and so has their impact.
Great numbers of quarries in a karst region amplifies the geomorphic impact (Sauro, 1993). Stanton (1966) suggested that the disturbance created by numerous smaller quarries is greater than that created by one large quarry and recommended that geomorphic disturbance be minimized by maximizing reserves through deep quarrying. (See section on ground water regarding the impacts of deep quarrying.) Stanton (1990) later suggested that limestone has more value in situ as a source of water and for its scenic value than as a source of crushed stone and recommended avoiding extraction of limestone altogether when alternatives are available. 

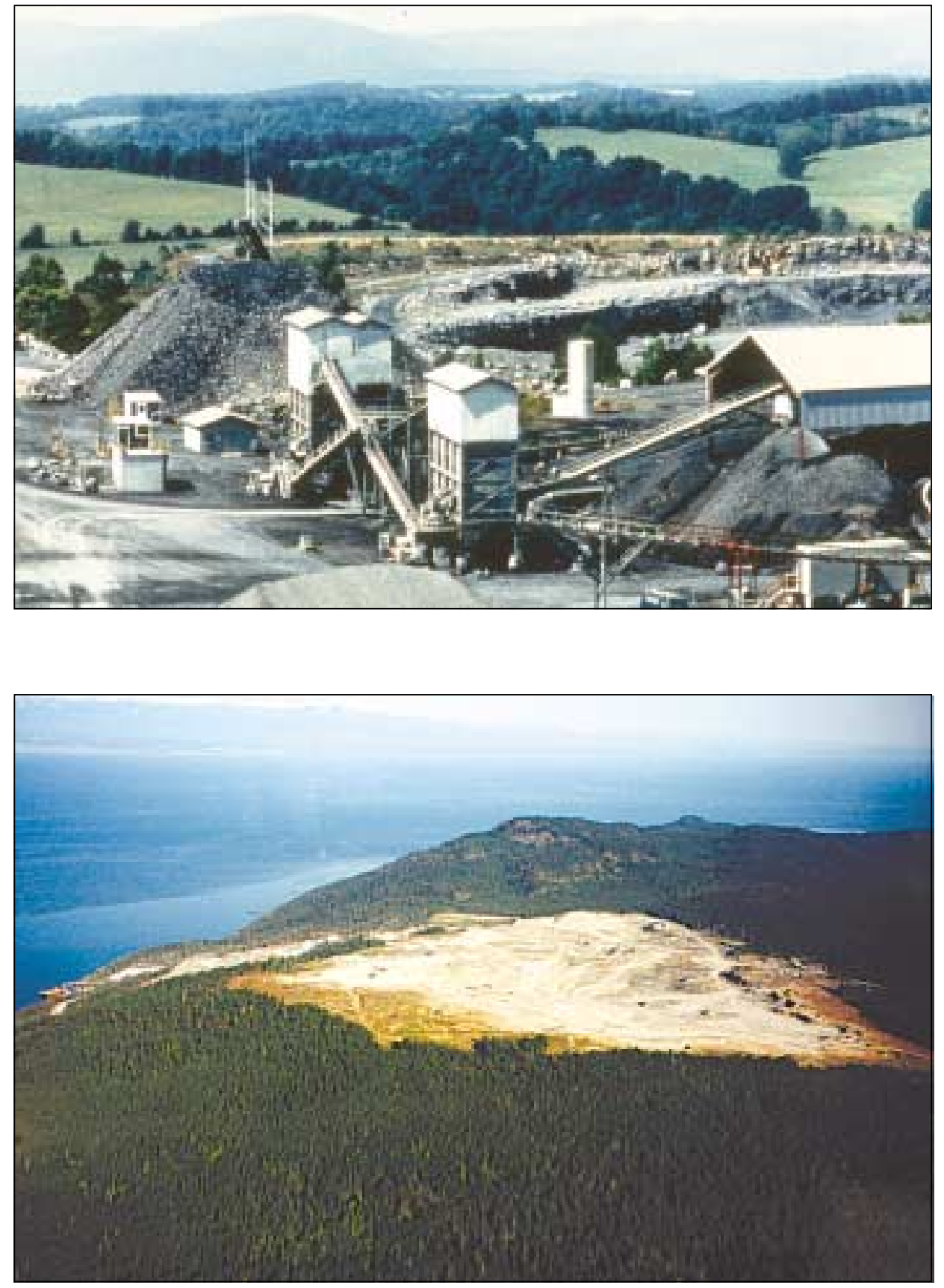

Figure 10 Engineering techniques, such as enclosing equipment and removing dust using vacuums, can mitigate impacts of noise and dust. (Photograph courtesy of Luck Stone.)
Figure 11 Quarries can occupy a signifi cant part of the visual landscape.
In broad terms there are three situations where quarries can be located: 1) on flat ground, 2) along or into the side of a valley, and 3) on the side of a hill (Gunn, 1993; Gunn and Bailey, 1993). In most situations, quarries excavated into flat ground have a relatively small impact on geomorphology, which is limited to the removal of sinkholes and cave passageways. Quarries on valley sides can extend laterally along the valley side causing large geomorphic impacts, or they can work back into the valley wall, where the impact is less (Gunn, 1993; Gunn and Bailey, 1993). Quarries on hills generally have a large geomorphic impact. Gunn (1993) reports that crushed stone quarrying has removed an entire karst hill and large portions of other nearby karst hills in the Mendip Hills, UK.

\section{Blasting}

One of the most frequent complaints the public makes to the crushed stone industry situated near population centers is about blasting noise (National Academy of Sciences, 1980). Blasting may occur daily or as infrequently as once or twice a year. The blasting techniques used in crushed stone operations are significantly different than those used in dimension stone quarrying. Whereas large amounts of explosives are used in crushed stone operations to produce appropriate-sized rubble (fig. 12), the dimension stone industry uses only small amounts of explosives to loosen large blocks of stone. 


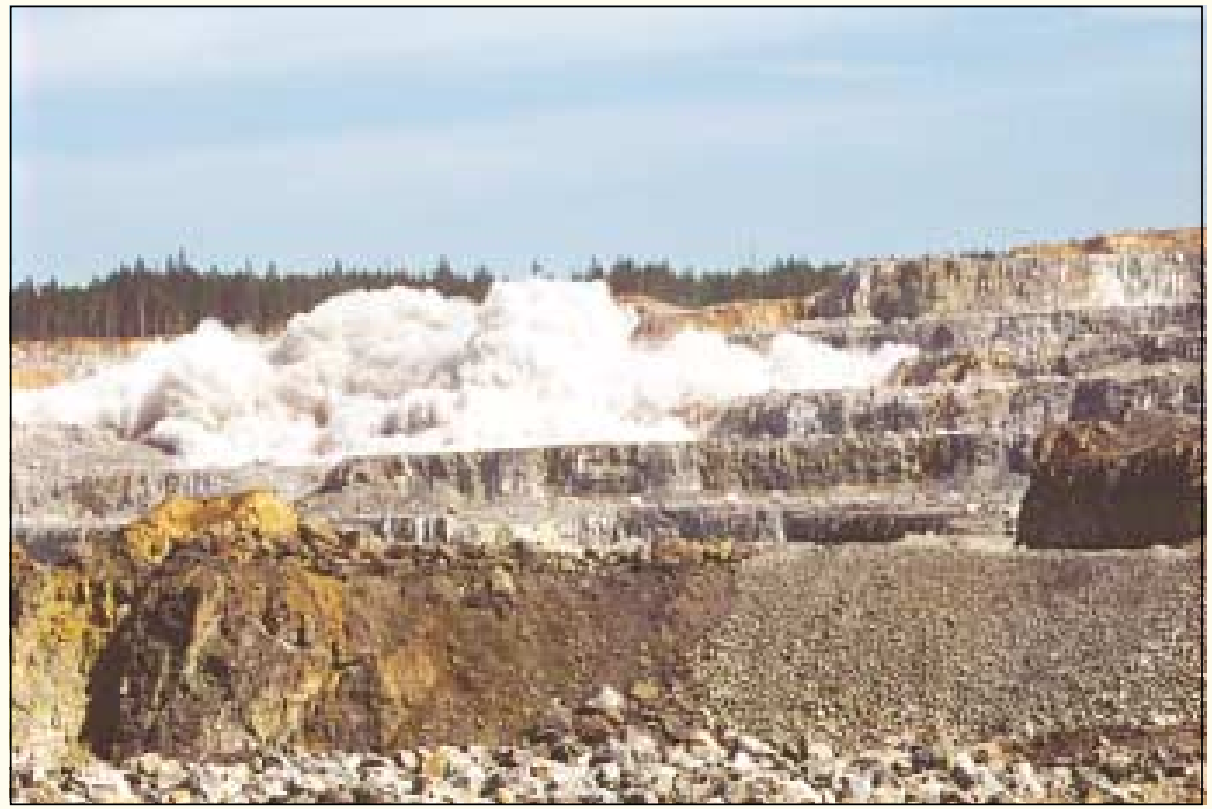

Figure 12 Rock is drilled and blasted for use as crushed stone. In some isolated areas where people are not located nearby, larger amounts of explosives may be used.

Geology, topography, and weather affect the impacts of blasting. Blasting noise generally increases with the amount of explosive, with specific atmospheric conditions, and with proximity to a blast. The area in front of a blast commonly receives more noise than an area behind a blast. People differ greatly in their response to blasting (National Academy of Sciences, 1980).
When an explosive is detonated enormous amounts of energy are released. Most of the energy of a properly designed blast works to displace rock from the quarry face. The remaining energy is released as vibrations through and along the surface of the earth and through the air. Most of the energy that goes through the earth comes to the surface within a few meters of the detonation and travels as surface waves, which may cause ground shaking. A small amount of the energy is transmitted through the rocks as shear waves, which commonly are insignificant

When a blast is detonated, some energy will escape into the atmosphere causing a disturbance in the air. Part of this disturbance is subaudible (air concussion) and part can be heard (noise). Air concussion is most noticeable within a structure, particularly when windows and doors are closed. The air concussion creates a pressure differential between the outside and inside the structure causing it to vibrate.

Poorly designed or poorly conhighly developed, and when blasting is properly conducted, most environmental impacts should be negligible. By fol-

lowing widely recognized and well-documented limits on ground motion and air concussion, direct impacts from ground shaking and air concussion can be effectively mitigated. Those limits and methods to measure them are discussed in Moore and Richards (1999), Bell (1992), Berger and others (1991), and National Academy of Sciences (1980). trolled blasts may cause rocks to be projected long distances from the blast site (flyrock), which can be a serious hazard. Flyrock is not commonly a problem with carefully designed and executed blasting plans, but is a situation that deserves careful attention. The pinnacled bedrock in karst can complicate blasting, increasing the risks for flyrock.
Blast-induced vibrations and shock waves can cause stalagmites and stalactites to break off and cause cave roofs to crack or collapse. Blasting may cause fracturing of quarry walls, increasing permeability and increasing drainage towards quarry face (Gagen and Gunn, 1987, Gunn and Bailey, 1993). The blast zone beneath the quarry floor in sub-

water table quarries may be considered as a separate aquifer with high fracture density, low primary porosity, and negligible conduit development (Smart and others, 1991).

Blasting-induced fracturing or aperture widening may play a role in initiating flooding events.

Lolcama and others (1999) describe a situation where blasting opened a conduit under the floor of a quarry. The conduit was connected to a nearby river and to a local water storage basin. Extensive grouting was required to stop the inflow of water from those sources.

Blasting can negatively impact karst biota and may cause problems with ground-water availability and quality (discussed below). 


\section{Noise}

The primary source of noise from extraction of aggregate and dimension stone is from earth-moving equipment, processing equipment, and blasting (see above). The truck traffic that often accompanies aggregate mining can be a significant noise source. The impacts of noise are highly dependent on the sound source, the topography, land use, ground cover of the surrounding site, and climatic conditions. The beat, rhythm, pitch of noise, and distance from the noise source affect the impact of the noise on the receiver (Langer, 2001). Topographic barriers or vegetated areas can shield or absorb noise. Sound travels farther in cold, dense air than in warm air and travels farther when it is focused by atmospheric inversions than when inversions are not present.

An important factor in determining a person's tolerance to a new noise is the ambient (background) noise to which one has adjusted. In general, the more a new noise exceeds the existing background noise level, the less acceptable the new noise will be. In an urban or industrial environment, background noise may mask noise from a quarry operation, whereas the same level of noise in a rural area or quiet, residential neighborhood may be more noticeable to people. Furthermore, ambient noise generally is an accumulation of noises and does not have a single, identifiable source. If the mining noise is identifiable, the perception of noise probably will be great. For example, the noise from a single backup alarm can often be picked out from an equally loud engine noise.
Crushed stone operators and dimension stone quarriers are responsible for assuring that the noise emitted from the quarry does not exceed levels set by regulations. The impacts of noise can be mitigated through various engineering techniques. Landscaping, berms, and stockpiles can be constructed to form sound barriers. Noisy equipment (such as crushers) can be located away from populated areas and can be enclosed in sound-deadening structures (fig. 13). Conveyors can be used instead of trucks for in-pit movement of materials. Noisy operations can be scheduled or limited to certain times of the day. The proper location of access roads, the use of acceleration and deceleration lanes, and careful routing of trucks can help reduce truck noise. Workers can be protected from noise through the use of enclosed, air-conditioned cabs on equipment and, where necessary, the use of hearing protectors. Worker safety may include regular health screening.

Noise can negatively impact karst biota (discussed below).

\section{Dust}

Dust is one of the most visible, invasive, and potentially irritating impacts associated with quarrying, and its visibility often raises concerns that are not directly proportional to its impact on human health and the environment (Howard and Cameron, 1998). Dust may occur as fugitive dust from excavation, from haul roads, and from blasting, or can be from point sources, such as drilling,

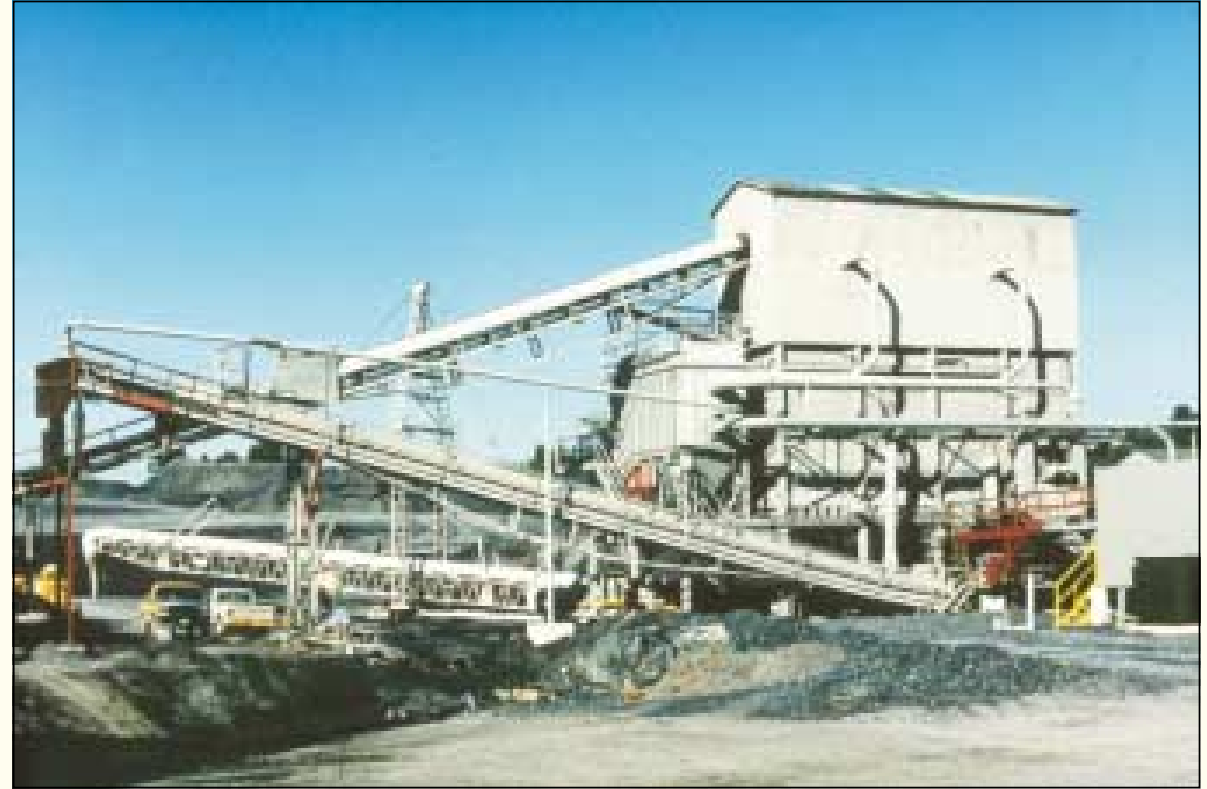

Figure 13 Noisy equipment can be located away frompopulated areas and can be enclosed in sound-deadening structures. (Photograph courtesy Luck Stone.)

crushing and screening (Langer, 2001). Site conditions that affect the impact of dust generated during extraction of aggregate and dimension stone include rock properties, moisture, ambient air quality, air currents and prevailing winds, the size of the operation, proximity to population centers, and other nearby sources of dust. Dust concentrations, deposition rates, and potential impacts tend to decrease rapidly away from the source (Howard and Cameron, 1998).

A carefully prepared and implemented dust control plan commonly can reduce impacts from dust (Kestner, 1994). Federal, state, and local regulations put strict limits on the amount of airborne material that may be emitted during site preparation and operation. Controlling fugitive emissions commonly depends on good housekeeping practices rather than control systems. Techniques include the use of water trucks, sweepers, and chemical applications on haul roads, control of vehicle speed, and construction of windbreaks and plantings (fig. 14). The impacts from plant-generated dust commonly can be mitigated by use of dry or wet control systems. Dry techniques include covers on conveyors, vacuum systems, and bag houses, which remove dust before the air stream is released to the atmosphere. Wet suppression systems consist of pressurized water (or surfactant treated water) sprays located at dust generating sites 
throughout the plant. Fugitive dust from blasting can be controlled by proper design and execution of blasts. Workers are protected from dust through the use of enclosed, air-conditioned cabs on equipment and, where necessary, the use of respirators. Worker safety may include regular health screening.

In some situations, dust on quarry floors and nearby areas can clog pores in the ground (fig. 15), thus altering recharge rates. In other situations, dust can enter conduits and smaller openings, and can be transported and deposited into caves (Gunn and Hobbs, 1999).

Dust can negatively impact karst biota (discussed below)

\section{Habitat and Biota}

Caves develop one of the most peculiar terrestrial ecosystems. One determining factor for life in karst solution features is the lack of light. The karst environment can be divided into four zones based on the degree of darkness (Vermeulen and Whitten, 1999):

1) The twilight zone, near the entrance where light intensity, humidity, and temperature vary and a large and varied fauna are found, 2) The transition zone of complete darkness, variable humidity and temperature where a number of common species live, some of which make sorties to the outside world, 3 ) The deep zone of complete darkness, almost 100 percent humidity, and constant temperature where fully cave-adapted species that never venture outside the cave live, and 4) The stagnant zone of complete darkness, 100 percent humidity, where there is little air exchange and carbon dioxide concentrations may become high.

Many species of bats, including nectar-feeding bats and insectivorous bats, roost in the twilight zone or transition zone of caves. Insectivorous bats make up the largest known colonies of mammals in the world (Veni and DuChene, 2001). Birds, other animals, and plants also inhabit these zones.

To cope with the permanent darkness, extreme scarcity of food, and relatively constant climate of the underground voids in the deep and stagnant zones, animals have developed physiological, behavioral, and morphological adaptations (fig. 16), losing many of the essential functions of aboveground species. Eyes are reduced or absent, and they have little or no pigment. These animals are able to cope with the highly alkaline environment created by the abundance of soluble calcium carbonate. They have developed means of expelling water in 100 percent humidity without losing body salts. If their ancestors had wings, cave animals have lost them. Diurnal rhythms are lost. Their life span increases and their fertility decreases dramatically. These adaptations have confined cave species to their habitat; they cannot survive elsewhere (Vermeulen and Whitten, 1999).

Figure 15 (right). Dust on quarry floors can clog pores in the ground, thus altering ground-water. recharge.

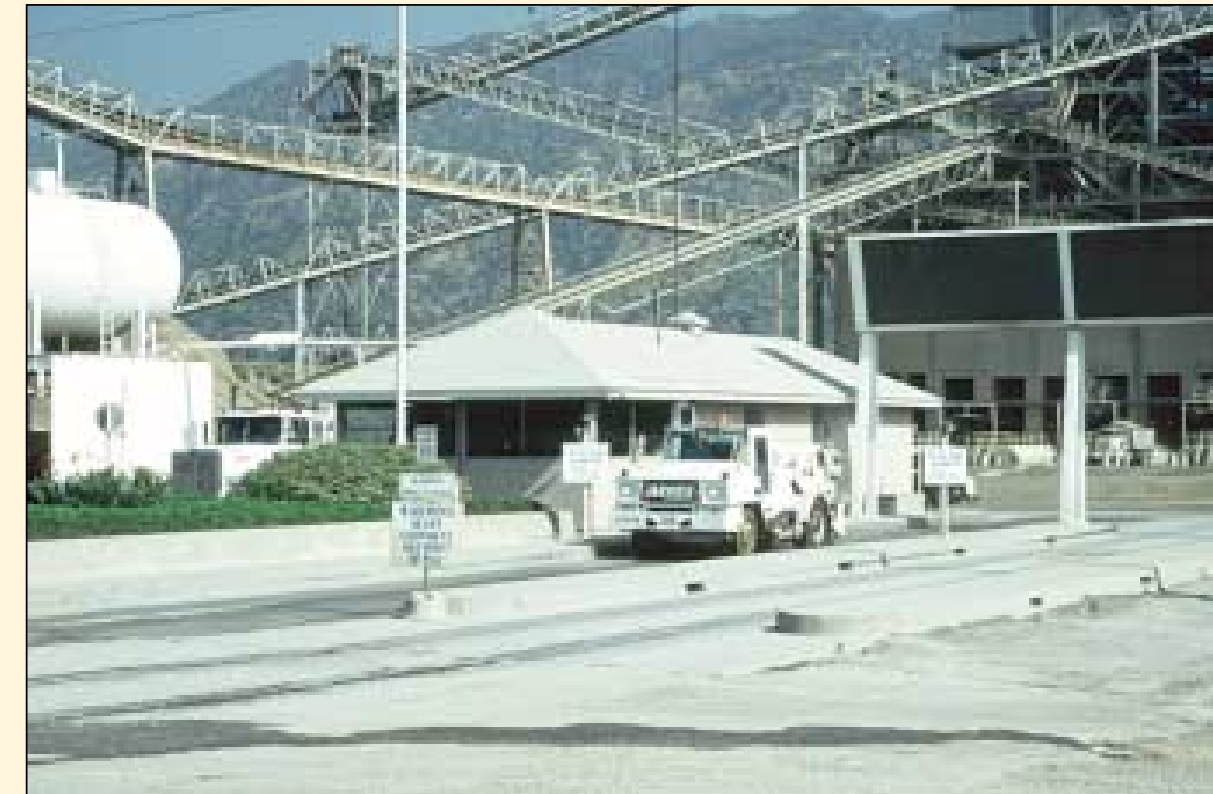

Figure 14 Dust control techniques include the use of water trucks and sweepers on haul.

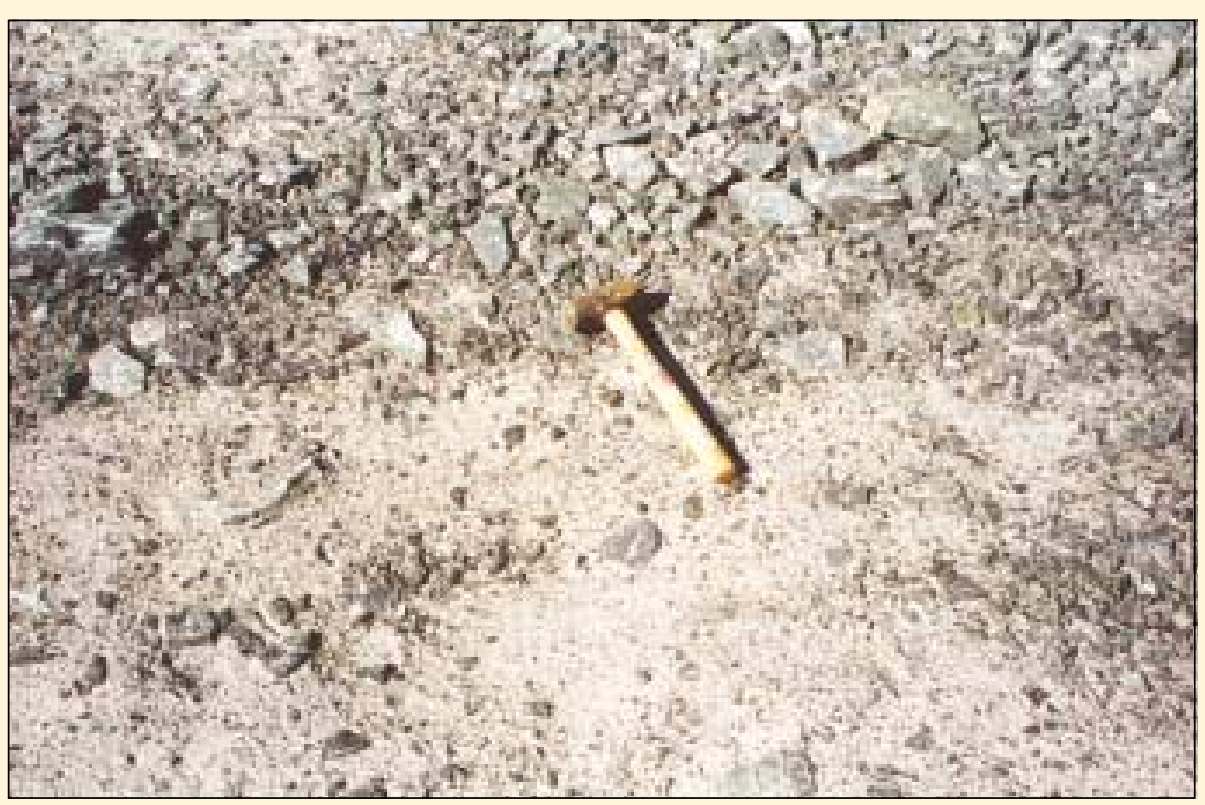



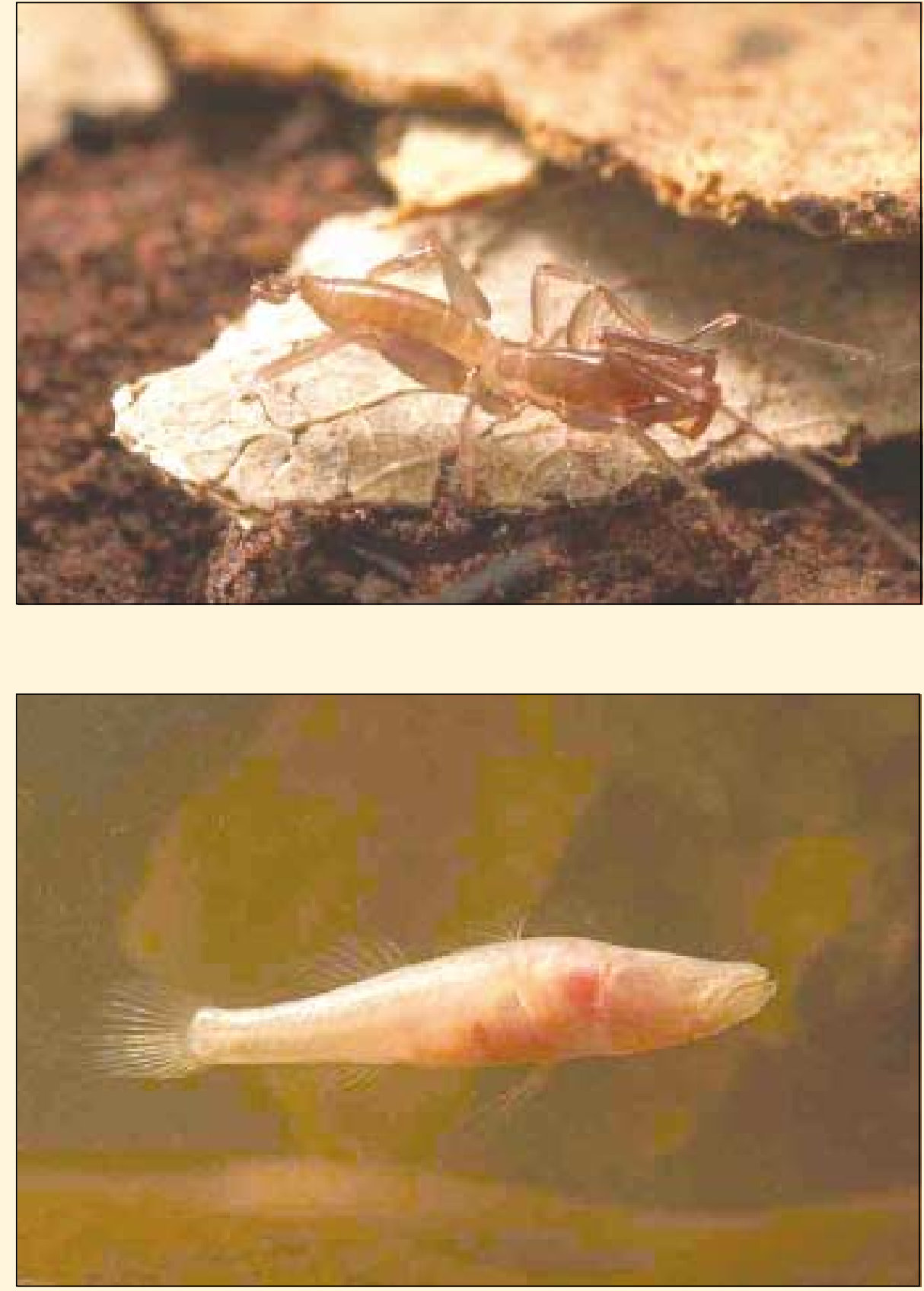

The biodiversity of karst ecosystems is highly restrictive. Some species are restricted to single cave systems and are little known. For example, about 47 species of aquatic and terrestrial invertebrates have been collected from the Movile Cave and nearby springs in southern Romania. Thirty of the 47 species were previously unknown and appear to be endemic to the system (White and others, 1995).

As rock is removed by quarrying, any cave passage is destroyed, along with any sediments it may have contained. The habitat provided by the caves and passages will cease to exist. Animals that inhabit the twilight or transition zone, and are mobile and able to find new homes, might survive; the rest will die. Creatures that have adapted to the deep and stagnant zones will perish.

Figure 16a (top left). Karst inhabitant - Bam azomus. (Photograph courtesy Elery Hamilton-Smith.)

Figure 16b(bottomleft). Karst inhabitant Milyeringa. (Photograph courtesy Elery Ham ilton-Smith.)
Quarrying may intersect active ground-water conduits, or cause their blockage, with adverse consequences for aquatic communities. Ground-water withdrawal and diversion of surface water may cause aboveground and underground hydrologic systems to dry up. Water bodies, which may be inhabited by small, site-endemic fish and snail species, will disappear and with them, the species. Alterations of flow volumes and patterns and the availability of nutrients can profoundly change the limestone environment and may lead to the extinction of whole communities (Vermeulen and Whitten, 1999). Lowering the water table will increase the thickness of the unsaturated zone, which can change the $\mathrm{pH}$ of the water in the unsaturated zone, which will change the biotic environment in small voids in the rock, which will kill species that live there.

Blasting can negatively affect karst habitat and biota. Blast-induced vibrations and shock waves can cause cave roofs to crack or collapse, and karst environmental conditions can be altered by just one new crack. Light may enter an otherwise dark cave or passage, or streams and ponds may suddenly drain into a new crack in the floor. Either situation can result in the death or displacement of cave communities (Vermeulen and Whitten, 1999). 
Noise and air concussion may disturb colonies of bats and swiftlets, causing them to leave their roosting sites.

This type of disturbance can occur as far away as 1,500 meters from the quarry if the opening of the roosting cave happens to be facing in the direction of the blast (Vermeulen and Whitten, 1999). Noise can adversely affect wildlife by inter-

fering with communication and masking the sounds of predators and prey, and in the extreme, result in temporary or permanent hearing loss (Fletcher and Busnel, 1978).

Dust, if uncontrolled, may spread over the surroundings during dry weather, leach into the soil during storms, and create harmful conditions for the flora and fauna (Vermeulen and Whitten, 1999). When dust smothers leaf surfaces, vegetation can be damaged through the blocking of leaf stomata, thus inhibiting gas exchange and reducing photosynthesis (Howard and Cameron, 1998).

Changes in the humidity of karst openings, presence of water, and quality of water (see below) can all impact karst biota. The impacts of quarrying on surface water and ground water (see below) can impact wetland riparian, and aquatic habitat which, in turn, can impact biota.

\section{Water Quality}

Karst systems have very low selfpurification capabilities (Kresic and others, 1992), which makes karst water very susceptible to pollution. A major concern is that polluted materials,

including pathogens, can be carried long distances without being filtered because of high flow velocities (several hundreds of thousands of meters per day) (Assad and Jordan, 1994)

The sources of pollutants do not necessarily have to be man-made; there also are natural sources of pollution (Kresic and others, 1992). Generally, karst occurs in areas that contain large amounts of organic material and bacteria, which can naturally degrade water quality. Erosion, especially at boundary areas between karst and nonkarst areas, and washout of terra rossa and clay residue from fissures can cause increased turbidity at karstic springs. Groundwater drainage from ore deposits act as natural pollutants.
Quarrying can substantially modify the routing of recharge and water quality may be degraded (Gunn and Hobbs, 1999). Commonly the first impact of quarrying is to remove the overlying vegetation and soil. In temperate areas removing vegetation and soil reduces evapotranspiration and increases the effective rainfall. Unless measures are taken to control runoff and sedimentation, deterioration of ground water is

likely. In some karst areas the soil overlying the rock normally is a zone of filtration and water purification (Gunn and Hobbs, 1999). In aggregate mining, the target limestone, if unsaturated, may also act as a protective cover for the underlying aquifer. If the protective soil cover or unsaturated rock is removed, the hole created by the mining may focus surface water to the ground-water system. If the surface water is contaminated, the ground water can quickly become polluted (Hobbs and Gunn, 1998; Ekmekçi, 1993).

Quarrying can cause sinkhole collapse, which can result in capture of surface water. In the Tournaisis area, southern Belgium, about thirty sinkholes opened up along the Escaut River downstream from the city of Tournai. As a consequence, the ground water was polluted by an extensive loss of contaminated river water into the karst aquifer (Kaufmann and Quinif, 1999).
Dust can enter conduits and smaller openings and can be transported by ground water (Gunn and Hobbs, 1999). The fine debris produced by the cutting of marble can be worked through the ground-water system during storm events (Drysdale and others, 2001).

Blasting may cause problems with ground-water quality, but may also be erroneously identified as a cause of problems. Spigner (1978) reported that shock waves from blasting operations loosened clay particles from solution cavities causing "muddying" of the ground water. Elsewhere, Moore and Hughes (1979) investigated the impact of quarry blasting on ground-water quality and determined there was no relationship between blasting and quality of water in wells in the situation that they studied.

The risk of ground-water pollution may increase if the direction of groundwater flow is modified. New source areas of recharge may be introduced, and those sources may contain contaminated water. This situation can arise because of ground-water pumping (Adamczyk and others, 1988; Sedam and others,

1988) or can occur if old choked passages are flushed and become operational again. Ekmekçi (1993) reported that blasting associated with quarrying may close existing karst ground-water passages, or may open up new passage, resulting in a change in direction of ground-water flow. 


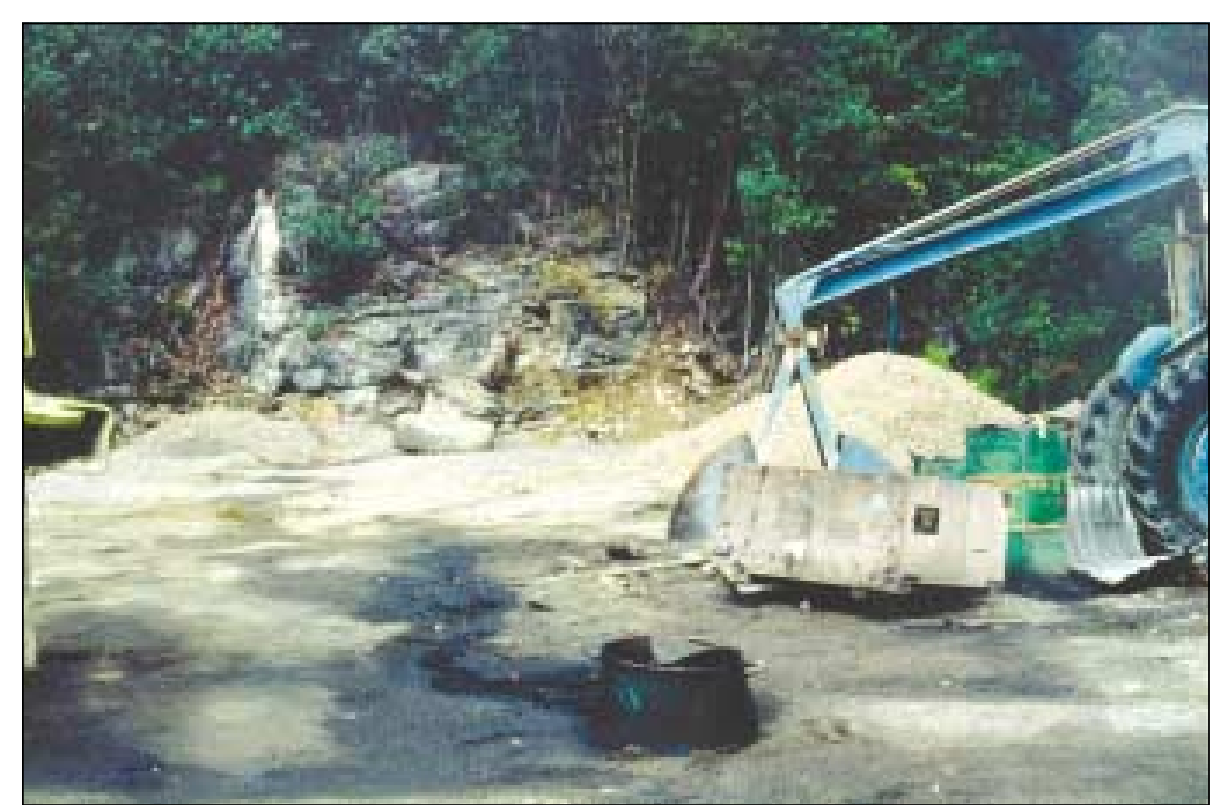

Figure 17a. Fuel oil spills can rapidly contaminate karst aquifers. (Photograph courtesy Elery Hamilton-Smith.)

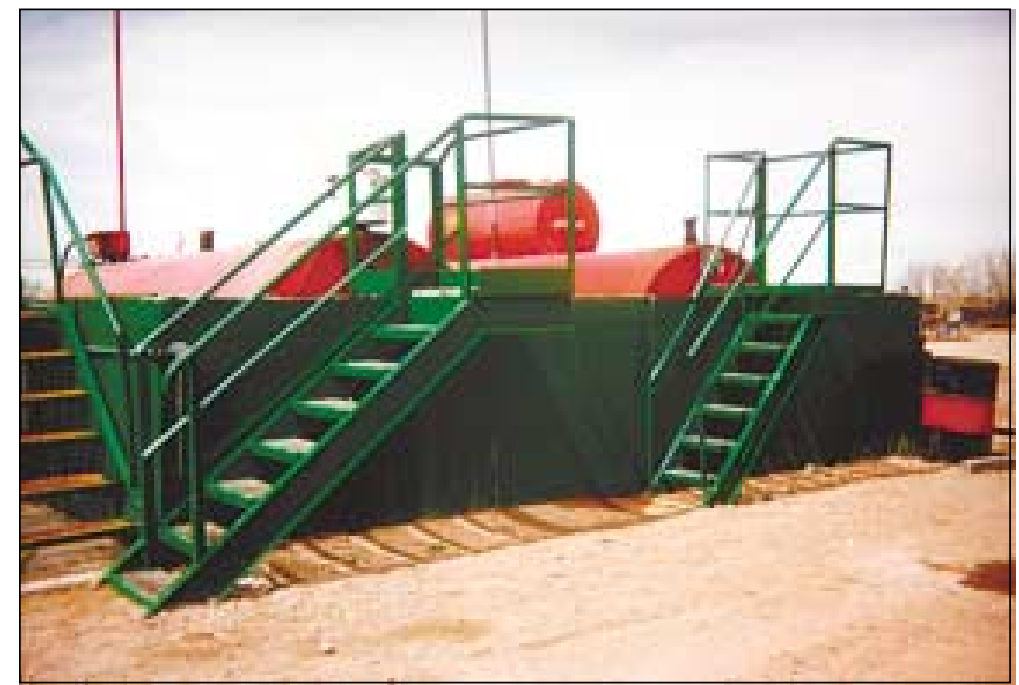

Figure 17a Properly constructed containment facilities can protect the aquifer frompotential fuel spills. (Photograph courtesy Lafarge.)
Large amounts of silt and other effluents from quarries (waste, fuel, oil) may pollute rivers as well as underground water bodies within and far beyond the boundaries of the limestone area (fig. 17a and b). Rivers in IndoChina, for example, host hundreds of species of large freshwater clams and snails, many of which are site endemic to a section of one stream. Development puts great pressure on these animals, which are very vulnerable because they are easily smothered in mud or killed by chemical pollution when silt is allowed to seep into a river. Fish communities are equally vulnerable (Vermeulen and Whitten, 1999).

\section{Surface Vater}

Engineering activities associated with quarrying can directly change the course of surface water. Sinkholes created by quarrying (see below) can intercept surface water flow. Conversely, ground water being pumped from quarries changes streams from gaining streams to loosing streams and can drain other nearby surface water features such as ponds and wetlands. Similarly, blasting (see above) can modify groundwater flow, which ultimately can modify surface water flow. Discharging quarry water into nearby streams can increase flood recurrence intervals.

\section{Ground Water}

Overall, quarrying in the unsaturated zone is likely to result in relatively local impacts such as increased runoff, reduced water quality, rerouting of recharge water through the aquifer, and localized reduction in ground-water storage. In karst areas, the unsaturated zone commonly contains only a small percentage of storage, and where the unsaturated zone is thin, impact on ground-water quantity generally is minimal (Hobbs and Gunn, 1998). However, Smart and Friederich (1986), Dodge (1984), and Gunn (1986) all describe areas where a thick, well-developed unsaturated zone is present. In those areas, the unsaturated zone may store significant quantities of water. Following rainfall, water may be collected and temporarily stored in the unsaturated zone, until it subsequently joins the ground-water system.

The major impact of quarrying in the karst saturated zone relates to quarry dewatering and the associated decline of the water table. It should be noted that there are many human activities other than quarrying that can affect groundwater levels, including municipal, industrial, and private ground-water withdrawals, irrigation, use of ground water for freeze protection, and mine drainage from other mineral resource extraction activities. Drought is a natural cause for water table declines. Many of the reports of dramatic declines of the water table refer to underground mines, rather than surface quarries. 
If quarrying intersects a phreatic conduit (a conduit in the saturated zone), the water-transporting function of that conduit will be severely impacted. Dye studies have demonstrated that, even without intersecting conduits, quarry dewatering can affect the function of a conduit by inducing leakage into diffuse flow zones (Edwards and others, 1991; Sedam and others, 1988). In cross section, the path of a conduit often has a wave shape. If the water table is lowered to where at least the crests of the waves no longer contain water, water will be trapped in the troughs of the waves and the conduits will no longer be able to transmit water.

If a quarry intersects the water table, ground water commonly will flow out of the rock into the quarry. Water may just trickle into the quarry or it may flow into the quarry at a rate of hundreds or thousands of liters per second (L/s), especially if quarrying intercepts a phreatic conduit. Foose (1953) reported an inrush of 500 to $630 \mathrm{~L} / \mathrm{s}$ that occurred when an underground limestone quarry intersected a conduit, and Lolcama and others (1999) reported a flow of about $2,525 \mathrm{~L} / \mathrm{s}$ when a surface quarry intersected a conduit that was in hydraulic connection to a nearby river. In some situations, it may be necessary to drain or pump the water from the quarry to protect people, quarry workings, and equipment.
Pumping from a quarry will reduce hydraulic head and, thus, draw down water levels in the rock draining into the quarry. In the simplest case, the part of the water table impacted by quarry dewatering would look like a downwardpointing cone that has been depressed into the water table, thus its name - cone of depression. If the quarry were the only major source of ground-water draw down in the area, it would be located over the apex of the cone of depression.

The actual shape of a cone of depression depends on many factors including the direction, volume, and velocity of water moving past the site; rock properties, including permeability of rock layers, attitude of rock layers, amount of fractures in the rock, size of fractures, fracture orientation, continuity of fractures, and regional stresses keeping fractures open or closed; other sources of ground-water withdrawals, natural or manmade discharge points, recharge points, conduits, whether conduits recharge or drain aquifer, and so forth. Homogeneous rocks yield a classic circular cone of depression, but the anisotropic nature of most limestones produces an irregular zone of depression, with preferential development along zones of highest permeability (Gunn and Hobbs, 1999). Depending on local conditions and quarrying practices, cones of depression can be almost as small as the quarry itself, or can be as large as $25 \mathrm{~km}^{2}$.

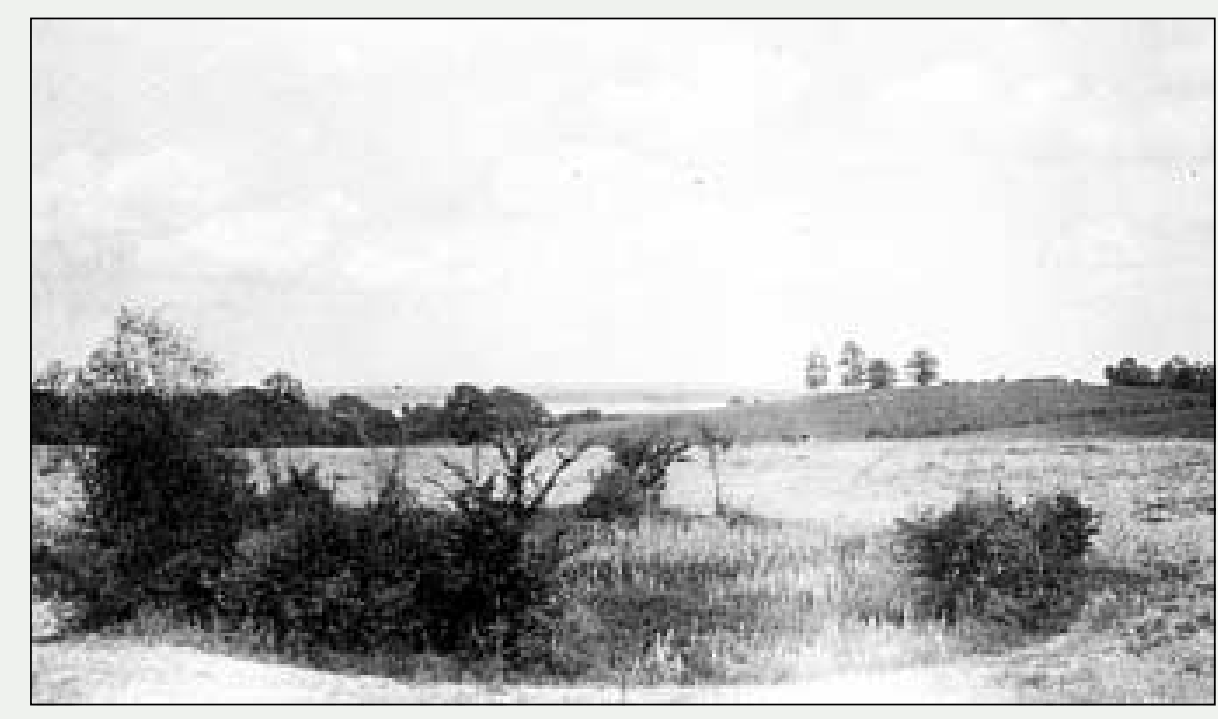

Figure 18 Natural sinkhole near Ste. Genevieve, Missouri (USGS photographic libraryShaw \#891).

Water pumped from a quarry is likely to be lost from the local groundwater system. Within the cone of depression, wells, springs, and streams can go dry or have their flows significantly reduced, and the overall direction of ground-water flow may be changed (Hobbs and Gunn, 1998). It is within this cone of depression that many humaninduced sinkholes are formed.

Karst aquifers are often separate from overlying shallow surficial aquifers. Fraser and Grapes (1998) determined that a shallow aquifer in drift and the underlying karstic limestone aquifer in South Wales are separate hydraulic systems with distinct water chemistries and distinct responses to hydraulic stress. They determined that dewatering the deep aquifer would not affect plant communities supported by the shallow aquifer.

\section{Sinkhole Collapse}

Sinkholes are depressions formed in karst by either slow, downward solution or rapid collapse of the land surface. Sinkholes in carbonate rocks occur world wide, with notable concentrations in the eastern USA, southeast Asia, and parts of Europe. Sinkholes can occur naturally or can be induced by activities of man (Newton, 1976). 

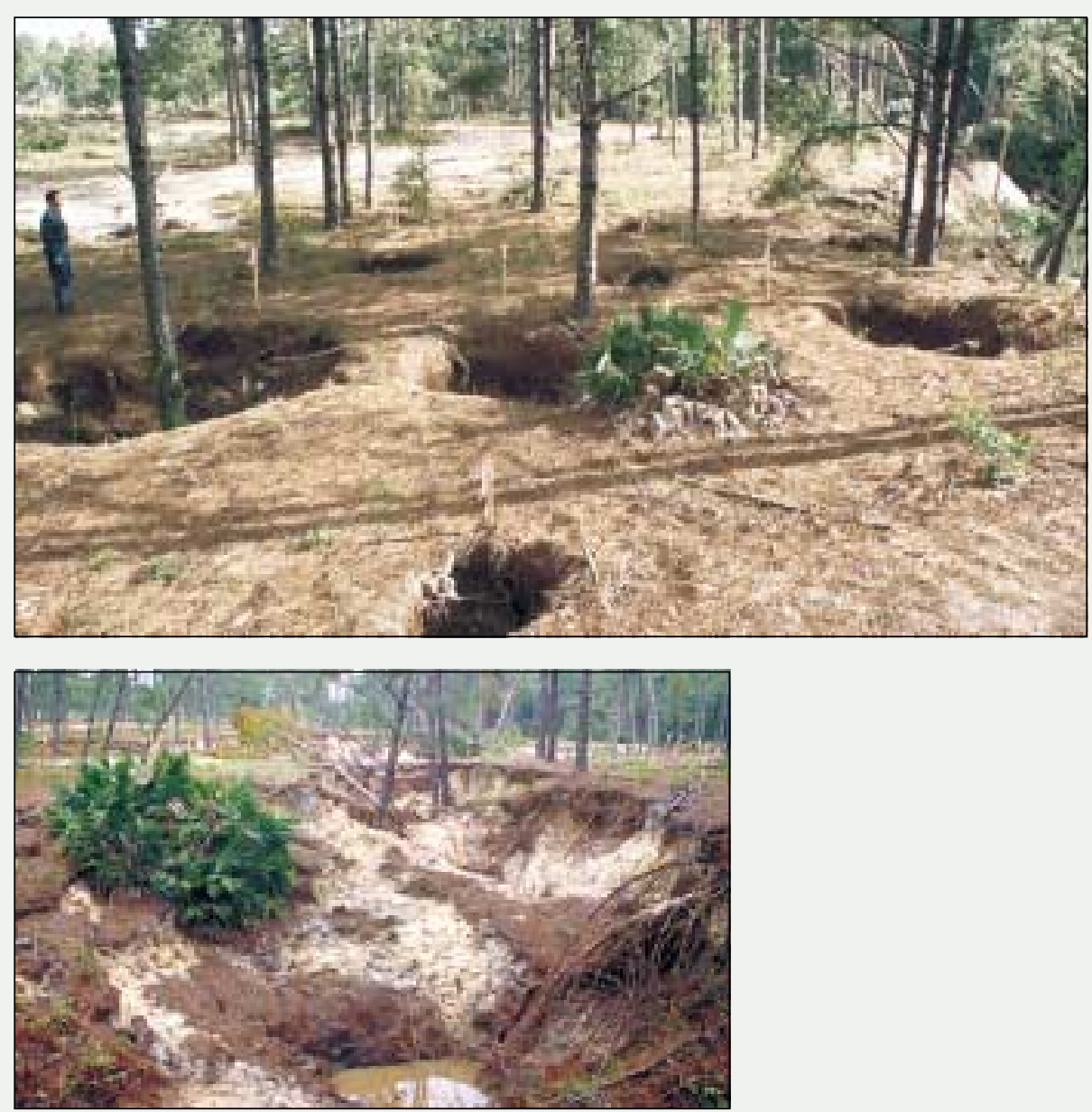

Figure 19 Human-induced sinkholes formed during the development of an irrigation well affected a 20-acre area and ranged in size fromless than 1 foot to more than 150 feet in diameter. (Photograph courtesy Ann Tihansky, USGS.)
Natural sinkholes (fig. 18) can form through the dissolution of rock (solution sinkhole) or through the failure of a bedrock roof overlying a cavern (collapse sinkhole). The formation of both of these types of sinkholes occur over periods of geologic time, not within a human lifetime. The solution of rock has little to do with the final cause of sinkhole collapse, however, it can set the stage for some human-induced event in the future (Thorpe and Brook, 1984; White and White, 1995). Of an estimated 4,000 sinkholes formed in Alabama between 1900 and 1976, only 50 were natural collapses (Newton, 1976).

Human-induced sinkholes are those caused or accelerated by human activities and commonly are characterized by catastrophic subsidence (Newton, 1976; LaMoreaux and Newton, 1986; LaMoreaux, 1997). If human activities had not taken place, these sinkholes would not have occurred, would not have occurred when they did, or, under natural conditions, would have occurred as subsidence, not rapid collapse (Newton, 1987). Human-induced sinkholes (fig. 19) commonly form as a result of ground-water withdrawal, construction activities, or a combination of both.

\section{Ground-Water Withdrawal}

Human-induced sinkholes in karst commonly are caused by human activities that lower the water table below the rock/soil interface (fig. 20). Many human activities, in addition to quarrying, can lower the ground-water table. While quarrying commonly is restricted to relatively small areas, other activities tcan be spread out, which may increase their relative impacts on the environment. Regardless, in some situations quarrying includes ground-water withdrawals and should be carefully addressed.

A classic case of sinkhole development caused by dewatering an underground limestone quarry occurred in the Hershey Valley, Pennsylvania (Foose, 1953, 1969; Foose and Humphreville, 1979). In 1949, increased pumping from the quarry created a cone of depression covering 600 hectares. Nearly

100 subsidence sinkholes formed above the cone of depression within three months of the increased pumping. Sinkhole development ceased after quarrying dewatering stopped and the water table returned to normal. 
Figure 20a. Hypothetical cross section showing karst area under conditions prior to quarry development. The water table (1) is generally above the soil / bedrock contact. Natural ground-water discharges to a spring (2), and a perennial stream(4), which support a wetland (3) and a riparian woodland (5). The surface of the bedrock is highly irregular (6), and is referred to as pinnacled bedrock. A natural sinkhole occurs where the water table is below the soil / bedrock contact (7)

Figure $20 \mathrm{~h}$ Hypothetical cross section showing karst area under worst-case conditions after quarry development. Under actual conditions, none, some, or all of these conditions may exist. Quarry dewatering has lowered the water table (1) below the soil / bedrock contact. Natural ground-water discharge to a spring (2) and perennial stream (4) has stopped, resulting in destruction of the wetland (3), drying up of the stream (4) and destruction of the riparian woodland (5). Underground cavities formed in the soil in the area of the pinnacled bedrock due to loss of buoyant support and piping (6). The ground above the cavity has subsisded, resulting in the formation of a wet area, and the tilting of fence posts or trees (7). Ultimately these cavities could collapse, creating a collapse sinkhole (8).
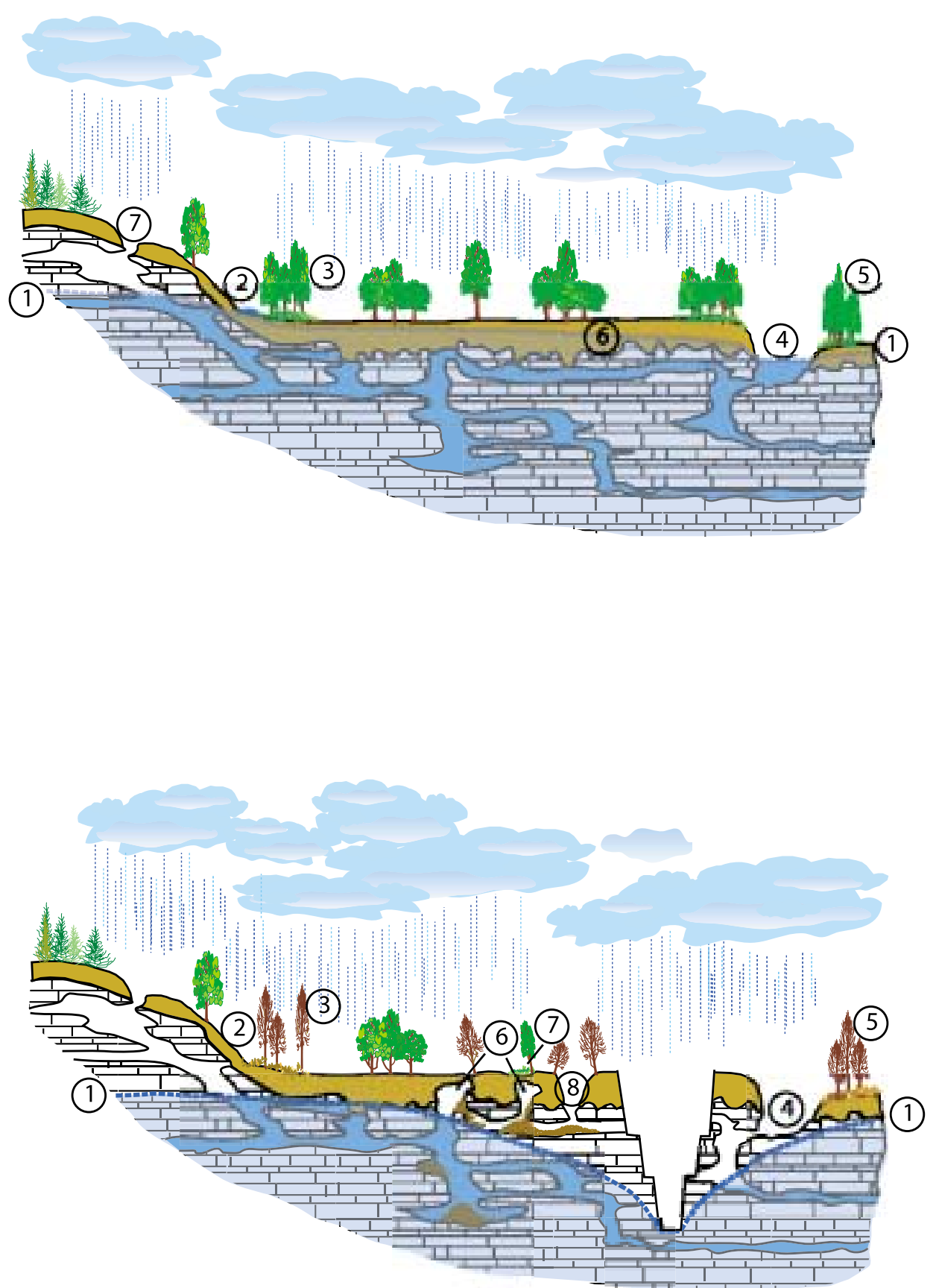
LaMoreaux and Newton (1986) document a similar occurrence in the Dry Valley area of Alabama where several thousand sinkholes formed above a cone of depression in the period 1967 1984. Ground-water withdrawals from two quarries in the Jamestown, South Carolina, area resulted in the formation of 42 sites of subsidence and collapse from 1976 - 1978 (Spigner, 1978;

Newton, 1987). Ground-water withdrawal caused by limestone quarrying appears to be the cause of sinkhole collapse at Railtown in northwestern Tasmania (Kiernan, 1989). Other areas of sinkhole collapse related to quarry dewatering have been described by Newton $(1976,1986,1987)$, and Newton and Hyde (1971).

Sinkhole collapse related to groundwater pumping can also result from some other dewatering activity in combination with quarrying. A number of sinkhole collapses near Calera, Alabama, occurred in an area dewatered by wells, quarries, and an underground mine (Warren, 1976). Intense pumping for domestic and industrial water supply, combined with dewatering of deep limestone quarries, has caused sinkhole development in the Tournaisis area, Belgium, since the beginning of the 20th century (Kaufmann and Quinif, 1999).
Quarrying begins at the top of bedrock and deepening occurs over a period of years. Sinkhole development may begin after quarrying penetrates the water table (fig. 20). When the depth below the water table is shallow, sinkhole development generally is confined to the vicinity of the quarry. As the quarry is deepened, the cone of depression enlarges and sinkholes occur further away (Newton, 1987). Sinkhole development following dewatering associated with subsurface mining commonly occurs more rapidly than that resulting from surface quarrying because the depth of dewatering and cones of depression are relatively large (Newton, 1987).

\section{Triggering Mechanisms}

The act of lowering the water table commonly does not by itself create a sinkhole. Most often land subsidence will occur only if support to overlying unconsolidated material is removed (Foose, 1967) and some other activity commonly "triggers" sinkhole formation. Triggering mechanisms include: 1) water level fluctuations, 2) loss of buoyant support by the water, 3 ) volume shrinkage, 4) piping or induced recharge, and 5) increased gradient and water velocity (fig. 21) (Newton and Hyde, 1971; Newton, 1987).
Subsidence or collapse of soil overburden into the fissures and caves of an underlying limestone creates subsidence sinkholes without involving failure of the rock (Waltham, 1989). Bedrock caves do exist beneath some sinkholes, but their role is merely to swallow the debris. Almost all sinkholes occur where cavities develop in unconsolidated deposits overlying solution openings in carbonate rocks (LaMoreaux and Newton, 1986), and given sufficient time, sinkholes can develop above bedrock containing only narrow rock fissures (Waltham, 1989).

\section{Water Level Fluctuations}

Pumping of ground water, particularly in seasonally-operated quarries, may result in ground-water fluctuations that are of greater magnitude than fluctuations that occur under natural conditions. The magnitude of fluctuation principally depends on the amount and duration of pumping and on the transmissivity and storage coefficient of the aquifer. The unconsolidated material bridging bedrock pinnacles can be weakened by the alternate wetting and drying, lubrication, and addition or subtraction of buoyant support brought about by fluctuating water levels (Newton and others, 1973).
Loss of Buoyancy Support

In some karst areas residual clay soil spans or fills space between bedrock pinnacles. If the soil is saturated, about $40 \%$ of the weight of the residual clay soil overlying a bedrock opening is supported by ground water (Newton and Hyde, 1971; Newton, 1987). When the ground-water level is lowered, buoyant support is lost (fig. 21, block B). The loss of buoyant support can trigger sinkhole collapse (fig. 21, block D) or cause spalling that ultimately trigger collapse. (Newton, 1984a, 1984b, 1984c, 1987).

In artesian areas, hydrostatic pressure provides support to the confining bed and to overlying material (Newton, 1987). Weakening of buoyant support in artesian carbonate rocks may be caused by a decline of piezometric levels of the confined aquifer system. A one meter decline in piezometric level corresponds to a $1 \mathrm{ton} / \mathrm{m}^{2}$ increase of effective loading of overburden. Local or distant withdrawals of karst aquifer could cause such a decline (Prokopovich, 1985). 


\section{Volume Shrinkage}

As ground water is lowered in areas of pinnacle weathering, volume shrinkage due to compaction of the unconsolidated debris takes place. If two pinnacles are less than $10-15 \mathrm{~m}$ apart, the weight of the sediment load between the pinnacles can be carried as an arch (Foose, 1967). As spalling occurs, the cavity grows upward, enlarging the vaulted roof. There is a limit to the weight that the arch can hold, and when the ability of the arch to hold the load is exceeded, rapid upward propagation of the arch by continuous spalling results in sudden collapse of the surface.

Soils with low cohesive strength, such as dry sands, tend not to form a stable arch. There is a continuous flow of soil down the drain (raveling) and instead of an abrupt collapse, the sinkhole forms by a process of continuous subsidence. Human influences, particularly dewatering, can greatly modify the rate of soil transport (Newton and others, 1973).

\section{Piping or Induced Recharge}

When cavities in the soil or bedrock are filled with ground water (fig. 21, block A), surface water cannot flow into the cavities. When the water table is lowered, the cavities drain, thus allowing the inflow of surface water. Surface water passes through the residual soil, eroding it and carrying it downward into the air-filled cavities by a process called piping or subsurface mechanical erosion (LaMoreaux, 1997) (fig. 21, block C). Soil is piped down into the bedrock creating a void within the soil mantle. As time passes, more and more soil is piped down the drain and the void grows with an arched roof held up only by the cohesive strength of the soil. Eventually, the void becomes too large for the soil arch to support its own weight and there is a collapse (fig. 21 block D). The fallen roof may obscure the bedrock surface and the drain. The freshly-formed sinkhole is usually roughly circular in outline and has near vertical walls (Lolcama and others, 1999; White and White, 1995). Piping is well-documented by observations of the pumping of "muddy water" during quarry dewatering (Foose, 1953, 1967). Piping is most active during periods of heavy or prolonged rainfall.

A

Prior to water table decline

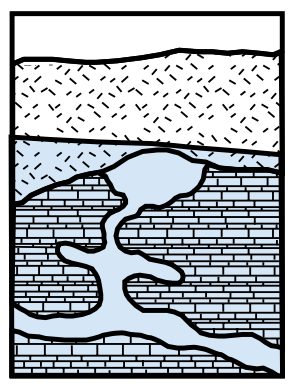

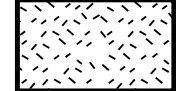

RESIDUAL CLAY SOI
B

Water table decline Loss of bouyant support
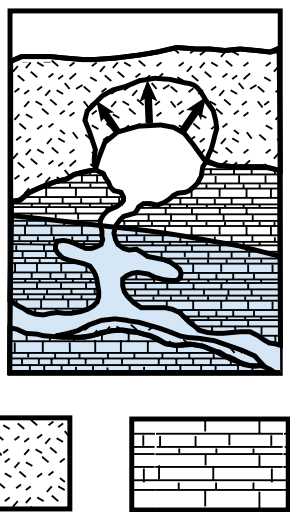

CARBONATE ROCKS

\section{c}

Water table decline Loss of bouyant Piping support or piping cause sinkhole collapse
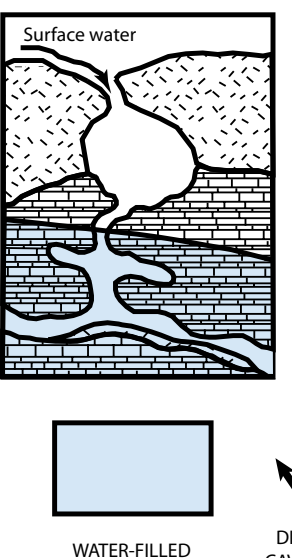

WATER-FILLED
OPENINGS

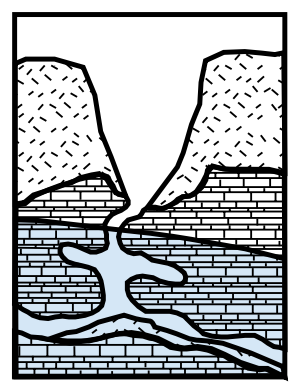

Figure 21 Diagramshowing mechanics of sinkhole development

\section{Increased Velocity of Ground Water}

Surface structures, such as storm drains, parking lots, and roof drains, concentrate recharge into a single inlet point in the carbonate rock, thus encouraging piping. Construction activities of various kinds can also raise hydraulic heads,

increase velocities in the drain, and thus also enhance the rate of sediment transport leading to accelerated sinkhole development (Newton, 1986).
Ground-water withdrawal creates an increased hydraulic gradient, which results in an increased velocity of ground-water movement. Increased water velocity results in flushing of sediments filling openings in cavity systems. In turn, downward movement of overburden sediments into newly created bedrock openings, results in a sinkhole (Newton, 1976, 1984a, 1984b, 1984c).

A decline in potentiometric surface under artesian conditions produces increased head differential, which results in increased velocity of recharge through the confining bed. The energy of this movement is diffuse, and unless the confining bed is breached, will not be expected to contribute to sinkhole development (Newton, 1987). 


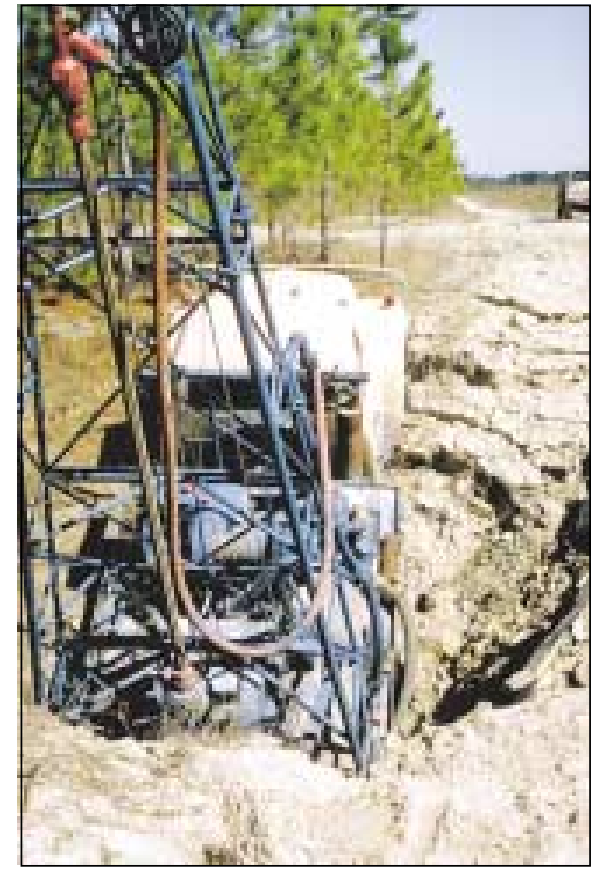

Figure 22 "A giant sink hole opened up on Thursday, September 19 [1975] at a drilling site near Tampa, Florida and swallowed up a well-drilling rig, a water truck, and a trailer loaded with pipe all valued at $\$ 100,000$. The well being drilled was down $200 \mathrm{ft}$ when the ground began to give way to what turned out to be a limestone cavern. Within 10 minutes all the equipment was buried way out of sight in a crater measuring $300 \mathrm{ft}$ deep, and 300 $\mathrm{ft}$ wide. Fortunately, the drilling crew had time to scramble to safety and no one was hurt." -fromNational Water Well Association newsletter. (Photograph courtesy TomScott.)

\section{Construction Activities}

Some sinkhole failures are induced by construction activities and are of major significance because they directly affect the site being developed, either immediately or some years later. Construction activities that can trigger sinkholes include 1) diversion or impoundment of drainage, 2) removing overburden, 3) drilling, augering, or coring 4) blasting, 5) loading, and 6) removal of vegetation. A lowered water table may leave sections of ground in a critical state awaiting construction activity to triggers their failure; however, even without a water-table decline, the same activity may prompt failure, but statistically less often.

Diversion or I mpoundment of Drainage

A major influence from construction is the diversion of natural drainage. Concentration of drainage at the surface, such as leaking pools, impoundments, pipes, canals, and ditches, can all create point discharge into the soil, inducing ground water to move through overburden into bedrock. This can result in an increased velocity of ground water, piping, saturation of overburden, and loss of cohesiveness of unconsolidated deposits (LaMoreaux, 1997). These effects can result in collapse of the overburden into openings below.
Runoff from roads or buildings commonly is disposed of into ditches, soakaway drains, or dry wells in soil over carbonate rock. Ditches and drainage wells cased into the limestone should perform safely, but, if poorly installed, leakage may cause adjacen or nearby failures (Crawford, 1986). In Pennsylvania, $7 \mathrm{~km}$ of highway induced 184 sinkholes along its associated drainage channels within 12 years (Meyers and Perlow, 1984).

\section{Removing Overburden}

Excavation of part of a soil cover may thin the roof of a soil cavity to a point of failure. Removal of a clay soil may permit drainage through previously sealed sands. Some Missouri railroads stand on banks made from soil excavated adjacent to them, and the marginal hollows frequently develop sinkholes (Aley and others, 1972).

\section{Drilling, Augering, or Coring}

These activities cause erosion of overburden into underlying openings. Unsealed boreholes can allow surface water to gain new access to the subsurface or may allow a perched soil aquifer to drain into a bedrock cavity. Drilling has resulted in collapses at or near working drill rigs (fig. 22) or the holes created (LaMoreaux, 1997). During 1960 an USGS driller was killed when a sinkhole formed around a test hole in Florida (Newton, 1987). Installation of wells at Westminster, Maryland, in 1940 and 1948 was associated with nearby sinkhole collapse (Newton, 1987). A sinkhole collapsed next to a USGS test well near Dickson, Tennessee, in May 1981 (Newton, 1987).

\section{Blasting}

Explosives create vibrations that can disturb the overburden and trigger its downward movement into solution openings in bedrock (Stringfield and Rapp, 1976; Ekmekçi, 1993; LaMoreaux, 1997). The village of Liangwu, in southern China, was abandoned when nearby blasting triggered 40 sinkholes, and another 100 followed soon after in an area 1800m long (Yuan, 1987). 


\section{Loading}

Heavy construction equipment and other traffic can disturb the overburden and trigger its downward movement into solution openings in bedrock (LaMoreaux, 1997). The weight of construction alone can trigger sinkholes (Newton, 1976).

\section{Removal of Vegetation}

The removal of vegetation permits increased infiltration and also deprives the soil of its root mat. In Alabama, sinkholes are more common in the parts of Dry Valley where timber has been cut (LaMoreaux and Newton, 1986) and failures occurred on a Birmingham, Alabama, construction site when foundation trenches stripped areas of topsoil (Newton and Hyde, 1971). Modern sinkhole development in Tasmania has been attributed to timber cutting and pasture development (Kiernan, 1989).

\section{Analysis of \\ Triggering Mechanisms}

Two independent studies, one in Missouri and one in Florida, indicate that altered drainage is the triggering mechanism responsible for over half of the sinkhole collapses. Williams and Vineyard (1976) conducted a study of 46 reported sinkhole collapses in Missouri and determined the cause of collapse to be; altered drainage ( 52 percent, water impoundments ( 22 percent), dewatering (15 percent), highway construction ( 7 percent), and blasting (4 percent). The Florida Department of Transportation analyzed 96 roadway-related collapses and determined the triggering mechanisms to be related to; heavy rainfall (58\% percent), construction (11 percent), lowering of the water table ( 8 percent), blasting ( 5 percent), drilling ( 5 percent), and other (11 percent). (Numbers do not add to 100 due to rounding.) Runoff collected during heavy rainfall is concentrated by highway drainage, thus supporting the findings of Williams and Vineyard (1976) that altered drainage is the dominant triggering mechanism for collapse (Thorpe and Brook, 1984).
Sinkhole Size, Occurrence, and Area I mpacted

Collapse sinkholes in fissured bedrock occur in the soil overlying cavernous bedrock, and the depth, therefore, is limited to the thickness of the soil.

In cavernous bedrock the depth of collapse sinkholes is limited to the combined depth of the soil and the cavern. The width of a collapse sinkhole near the surface depends on the thickness of the soil and on the slope stability, which, in turn, relates to the cohesiveness of the soil (Waltham, 1989). Geometry dictates that thick soils develop sinkholes with greater diameters than thin soils (White and White, 1995). Cohesive clayey soils maintain steeper slopes that sandy soils with low cohesiveness and, consequently, maintain wider sinkholes.
Size

Data relating to the size of sinkholes resulting from ground-water withdrawals are limited and not all the figures below refer to sinkholes related to quarrying. Sinkhole collapses in general range from $1 \mathrm{~m}$ to $145 \mathrm{~m}$ in their longest dimension. One of the largest sinkholes resulting from the withdrawal of ground water from carbonate rocks in Alabama is about $145 \mathrm{~m}$ long, $115 \mathrm{~m}$ wide, and 50 $m$ deep (LaMoreaux and Warren, 1973) (fig. 23). A study of an area in the Birmingham, Alabama, containing over 200 sinkhole collapses (Newton and Hyde, 1971) reported that the average sinkhole was $3.7 \mathrm{~m}$ long, $3 \mathrm{~m}$ wide, and $2.4 \mathrm{~m}$ deep. A similar study of an area near Greenwood, Alabama, containing over 150 sinkholes (Newton and others, 1973) reported that the average elongated sinkhole was about $6.1 \mathrm{~m}$ long, $4 \mathrm{~m}$ wide, and $2.1 \mathrm{~m}$ deep. Some sinkholes near Sylacauga, Alabama, (Newton, 1986) had surface diameters of 9 to 30 m. In Shelby County, Alabama, (Newton, 1986) six collapses had diameters approaching or exceeding $30 \mathrm{~m}$. Collapse sinkholes near Orlando, Florida, have a mean diameter of $9.4 \mathrm{~m}$ and a mean depth of $4.7 \mathrm{~m}$ (Wilson and Beck, 1992). A collapse sinkhole in central 


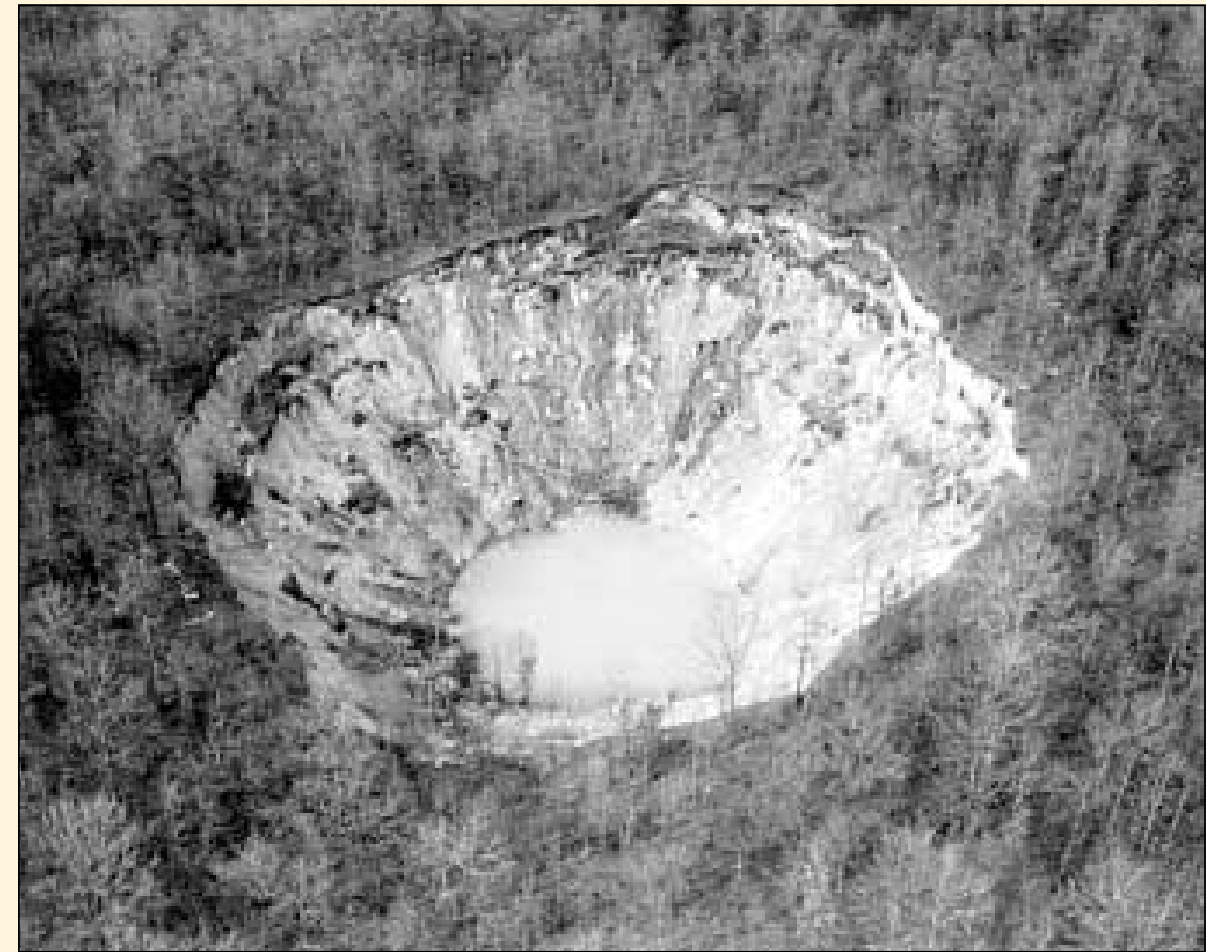

Figure 23. The "December giant," a large sinkhole, developed rapidly in Shelby County, Alabama, in December 1972. The sinkhole measures 145 mlong, 115 mwide, and 50 mdeep. (USGS Photographic Library-USGS \#40.)

Maryland (Martin, 1995) was approximately $9 \mathrm{~m}$ in diameter and 6-7 $\mathrm{m}$ deep. Collapse sinkholes resulting from quarry dewatering in North Carolina are up to $5 \mathrm{~m}$ in diameter and $3 \mathrm{~m}$ deep (Strum, 1999). Sinkholes in Pennsylvania (Kochanov, 1999) generally range from $1.2 \mathrm{~m}$ to $6.1 \mathrm{~m}$ in diameter and have approximately the same range in depth. In Hershey Valley, Pennsylvania, (Foose, 1953) 100 new sinkholes were reported to be near Tampa, Florida, also has these dimensions (Sinclair, 1982).
Occurrence

The numbers of collapse sinkholes that occur in an area and the size of the effected area varies from a single sinkhole in (about $1 \mathrm{~m}$ ) to about 1,000 sinkholes in area of about $45 \mathrm{~km} 2$. Seven sinkholes developed at a distance of $600 \mathrm{~m}$ from a quarry in North Carolina (Strum, 1999). Newton (1986) similarly reports that most induced sinkholes in Alabama related to quarry operations were found within $600 \mathrm{~m}$ of the point of withdrawal. In contrast, Sowers (1976) reports that quarries less than $60 \mathrm{~m}$ deep near Birmingham, Alabama, have been related to sinkhole development as far away as $1.6 \mathrm{~km}$. Sinclair (1982) also reports that 64 collapses occurred within a $1.6 \mathrm{~km}$ radius of a well field near Tampa, Florida. In one area in Alabama, an estimated 1,700 collapses or related features have occurred in five areas with a combined area of $36 \mathrm{~km} 2$ (Newton, 1976). In another area of Alabama, it was estimated that 1,000 collapses or other related features formed in an area of about $41.5 \mathrm{~km} 2$ (Warren and Wielchowsky, 1973). Near Jamestown, South Carolina, 42 collapses occurred within a cone of depression (Spigner, 1978). In Pennsylvania, about 100 collapses occurred in a cone of depression near Hershey where the ground-water surface had been lowered in an area greater than $25.9 \mathrm{~km} 2$. Impacts were observes $2.4 \mathrm{~km}$ from the point of dewatering (Foose, 1969; Foose and Humphreville, 1979). At Friedensville, Pennsylvania, 128 sinkholes formed from 1953-57 in an area around the point of withdrawal at a zinc mine, and 25 new sinkholes were recorded during a four-month period ending January 1971 (Newton, 1987; Metsger, 1979). Sites of similar intense development, in addition to those described above, were identified in Alabama, Georgia, Maryland, North Carolina, Pennsylvania, South Carolina, and Tennessee (Newton, 1986).

\section{Area Impacted}

The size of the impacted areas varies with the amount of ground-water withdrawal. Rates of withdrawal at the Friedensville zinc mine were between 440 and 1,310 liters per second (L/s), and the cone of depression covered an area exceeding $10.3 \mathrm{~km} 2$ (Newton, 1987; Metsger, 1979). Pumping by wells, quarries, and an underground mine west of Calera, Alabama, exceeded $883 \mathrm{~L} / \mathrm{s}$, creating a cone of depression of about 26 km2 (Newton, 1976, 1987; Warren, 1976). Ground-water withdrawal from two quarries with a combined rate in excess of $1,575 \mathrm{~L} / \mathrm{s}$ has lowered water levels in wells over $2.4 \mathrm{~km}$ from the quarries (Spigner, 1978). Near Hershey, Pennsylvania, an average of $347 \mathrm{~L} / \mathrm{s}$ of water was pumped from the underground quarry, impacting areas $2.4 \mathrm{~km}$ away (Foose, 1953, 1969). In Craven County, North Carolina, a quarry pumped at a rate of about $440 \mathrm{~L} / \mathrm{s}$, which resulted in sinkholes 600 m away (Strum, 1999). 


\section{Predicting Collapse Sinkholes}

It is only possible to predict sinkhole subsidence events in the broadest of terms. However, it is possible to identify zones where sinkhole risk is increased. A number of researchers have identified specific karst features that are diagnostic in pinpointing areas having a likelihood of collapse and subsidence. Williams and Vineyard (1976) cited nine features that can foretell of collapse or subsidence in karst terrain. Foose (1969) lists seven conditions that are common in areas of karst topography subject to collapse. Aley and others (1972) described seven features of karst terrain where catastrophic collapse had occurred, although they were primarily concerned with collapses induced by construction of impoundments.

The indicators cited may have limited regional usefulness because of the tremendous number of variables among various karst terrains and the various climatic conditions in those terrains. While this report is not intended to challenge the significance of the indicators, it is important to remember that the physical properties of karst are the result of local conditions.
Guidelines that repeatedly emerge from case studies is that sinkhole development most commonly occurs where four conditions exist: 1) residual soil overlies pre-existing fractures or cavities in pinnacled carbonate bedrock; 2) a solutionally widened fracture or shaft leading down into bedrock can act as a drain to transport sediment; 3 ) there is some provision to store or remove soil from the drain; and 4) the water table has declined past the bedrock/soil contact (Waltham, 1989; White and White, 1995).

Collapse sinkholes form most often where and when the water table first declines past the bedrock/soil contact. This condition occurs where the water level, previously above the bedrock/soil contact during all or most of the year, is maintained below the contact by ground-water withdrawal (Waltham, 1989; Newton, 1987; LaMoreaux and Newton, 1986; Foose, 1969). All the mechanisms that trigger sinkhole development in unconsolidated deposits can be activated by the decline in water table (LaMoreaux and Newton, 1986).

LaMoreaux and Newton (1986) state that sinkholes will not occur in areas where the water table was below the bedrock/soil contact prior to dewatering. However, Foose (1969), states that sinkholes have formed where the original water table was below the bedrock/ soil contact as a consequence of flushing out underlying bedrock openings during ground-water lowering.
Wilson and Beck (1992) relate sinkhole occurrence in Florida to declines in the potentiometric surface. When the surface declines $3 \mathrm{~m}$ below its mode, more than 10 times as many collapse sinkholes as expected per unit of time begin to occur.

Many authors also pointed out that sinkholes occur where the bedrock weathering is irregular, where the bedrock is pinnacled, or where there are extensive cavernous openings and major structural elements in the underlying bedrock (Foose, 1968; Newton, 1984a 1984b, 1984c; Waltham, 1989).

The thickness of the residual soil has some control on the likelihood of collapse sinkholes, although the actual values appear to be site and soil-type dependent. Williams and Vineyard (1976) pointed out that sinkhole collapses are more likely to occur in residual soil ranging in thickness from 12 to $30 \mathrm{~m}$. Foose (1969) observed that few sinkholes occur where the overburden is less than $10 \mathrm{~m}$ thick. Waltham (1989) states that the most hazardous zone is where the soil is 2 to $20 \mathrm{~m}$ thick. Sinclai and Stewart (1985) state sinkhole collapses are rare where limestone is at surface or the ground is thinly covered with soil; sinkhole collapse is common where overlying material is $5-50 \mathrm{~m}$ thick, especially between 5 and $25 \mathrm{~m}$ thick; sinkhole collapses are found but are rare in areas of soil cover over $50 \mathrm{~m}$ thick. Williams and Vineyard (1976) pointed out that sinkhole collapses are more likely to occur in residual soil that retains the fabric of the parent material and in soil where the clay fraction has low plasticity common to kaolinitic and halloysitic clays.
Geomorphology influences collapse sinkhole formation. Newton (1984a) reports induced sinkhole formation is most common in terrain that is geomorphically youthful, exhibits little karstification, is usually a lowland area, has a water table above or near the top of bedrock, and contains perennial or nearperennial streams. Williams and Vineyard (1976) found that collapses are more likely to take place in valleys with losing streams and watersheds than in gaining ones. Waltham (1989) states that the most hazardous zone is a valley floor. Many collapse sinkholes occur where concentrations of surface water are greatest, such as streambeds, natural drains, or poorly drained areas. Wilson and Beck (1992) report that near Orlando, Florida, 85 percent of new sinkholes occur over high recharge areas on slightly elevated, sandy ridges. Few or no sinkholes occur in discharge areas where net downward erosion of surficial sediment is very unlikely. Kaufmann and Quinif, (1999) related sinkhole orientation in southern Belgium to structure, and reported that almost every sinkhole they investigated lies in three parallel linear zones that reflect the orientation of a shear fault about $1 \mathrm{~km}$ away. 
Hobbs and Gunn (1998) outline a method to characterize the nature of a karst aquifer in terms of the likelihood of impacts from carbonate rock extraction on the ground water. They classify carbonate aquifers into four groups based on storage, type of flow, and type of recharge. Storage ranges from high to low; flow ranges from conduit to diffuse, and recharge ranges from concentrated to dispersed.

- Group 1 represents aquifers with high storage, conduit flow, and variable recharge.

Predicting the impact of quarry dewatering is very difficult and is dependent on the likelihood of the workings intersecting an active conduit.

- Group 2 represents aquifers with low storage, conduit flow, and variable recharge.

Predicting the impact of quarry dewatering is very difficult, but with low storage, the number of water supplies and size of springs supported by the aquifer is likely to be small.

- Group 3 represents aquifers with low storage, diffuse flow, and dispersed recharge. These are thin limestones with seasonal springs and typically are minor or non-aquifers.

These aquifers present no problem from a geohydrologic point of view, and the potential impact can easily be predicted by treating them as homogenous aquifers.
- Group 4 represents aquifers with high storage, diffuse flow, and variable recharge. These aquifers provide a useful resource and may support moderately large springs that may, in turn, provide stream base flow. The potential impact can easily be predicted by treating them as homogenous aquifers.

A holistic systems analysis technique to investigate impacts of aggregate extraction on the environment is described by Langer and Kolm (2001). The method requires analyzes of various systems making up the environment, including land surface, geomorphic, subsurface, and ground-water systems (Kolm, 1996). After system characterization is complete, the method focuses on risk analysis techniques for identifying and evaluating potential environmental impacts to determine acceptable mining strategies (Langer, in press).

There may be warning signs of impending sinkhole collapse. There may be slow localized subsidence and, although new depressions may be hard to identify, the depressions may be enhanced by the ponding of water. Circular cracks may appear in the soil or pavement. Fence posts or other objects may be tilted from the vertical. Vegetation may be distressed due to lowering of the water table. Muddy water in wells may indicate the early stages of a nearby developing sinkhole.

\section{Reclamation}

Reclamation commonly is considered to be the start of the end of environmental impacts from mining. The development of mining provides an economic base and use of a natural resource to improve the quality of human life.

Equally important, properly reclaimed land can also improve the quality of life. Wisely shaping mined out land requires a design plan and product that responds to a site's physiography, ecology, function, artistic form, and public perception.

There are numerous examples of successfully reclaimed aggregate quarries, including residential, commercial, recreational, and natural uses (Arbogast and others, 2000). Many of the examples are independent of rock type. However, there are a few studies that relate specifically to reclamation of carbonate rock quarries to near natural conditions.

The oldest design approach around is nature itself. Given enough geologic time, a suitable small site scale, and stable adjacent ecosystems, disturbed areas may recover without mankind's input. Ursic and others (1997) studied the Niagara Escarpment and recognized natural cliffs as special places that provide refuge for rare species of plants and animals. They also inventoried vegetation on the walls of 18 carbonate rock quarries abandoned from 20 to 100 years ago and discovered that many of the older quarry walls naturally revegetated in such a way as to replicate the biodiversity of natural landforms.
In other areas, long-term natural recovery alone may not bring about the specific changes people find desirable. The natural reclamation process of abandoned quarries can be accelerated through a process called landform replication. Through carefully designed blasting, referred to as restoration blasting, talus slopes, buttresses, and headwalls of carbonate rock quarries can be created that can be revegetated to produce landform and plant assemblages similar to those that occur on natural valley sides (fig. 24) (Gunn and Bailey, 1993; Gunn and others, 1997).

Gillieson and Houshold (1999) describe reclamation projects in Australia that are specifically designed to return carbonate rock quarries to as close as possible to their original state. The key issues were the integrity of the underground drainage, its water quality, and the cave invertebrate populations. 


\section{Legal Aspects}

The legal situation concerning induced sinkholes and other environmental impacts in karst is reviewed by Quinlan (1986), LaMoreaux (1997), and LaMoreaux and others (1997).

Quinlan (1986) summarizes case law, legal concepts of ground water and surface water, liability, and law review articles. He reviews the rationales of plaintiffs and defendants, including the allegations that serve as the basis of liability for damages and the defenses against those allegations.

LaMoreaux (1997), and LaMoreaux and others (1997) primarily discuss regulatory standards and the geologic and hydrologic conditions that lead to legal disputes. The authors point out that nearly every State in the United States has implemented legislation, rules, and regulations that apply in part or totally to karst terrain and give examples of State and local laws.
An example of the difficulties in determining the proximate cause of a sinkhole is demonstrated by the investigation of a catastrophic sinkhole that occurred near Westminster, Maryland (Gary, 1999). On March 31, 1994, a sinkhole opened up in the middle of a State road. The sinkhole measured approximately $8 \mathrm{~m}$ by $6 \mathrm{~m}$, and was 4.5 $m$ deep. A man drove into the sinkhole and was killed. An active quarry operation was located about $600 \mathrm{~m}$ away, and two municipal water supply wells were within $1.6 \mathrm{~km}$ of the sinkhole. An isolated pinnacle of limestone occurred in the center of the roadway alignment. A dye trace was conducted to determine if there was a hydraulic connection between the sinkhole and the quarry or other pumping locations. Sampling stations were placed throughout the surrounding valley and in the nearby quarry. There was no dye recovered in the sample sites, therefore, there was no conclusive evidence that quarry dewatering was the cause for the sinkhole.

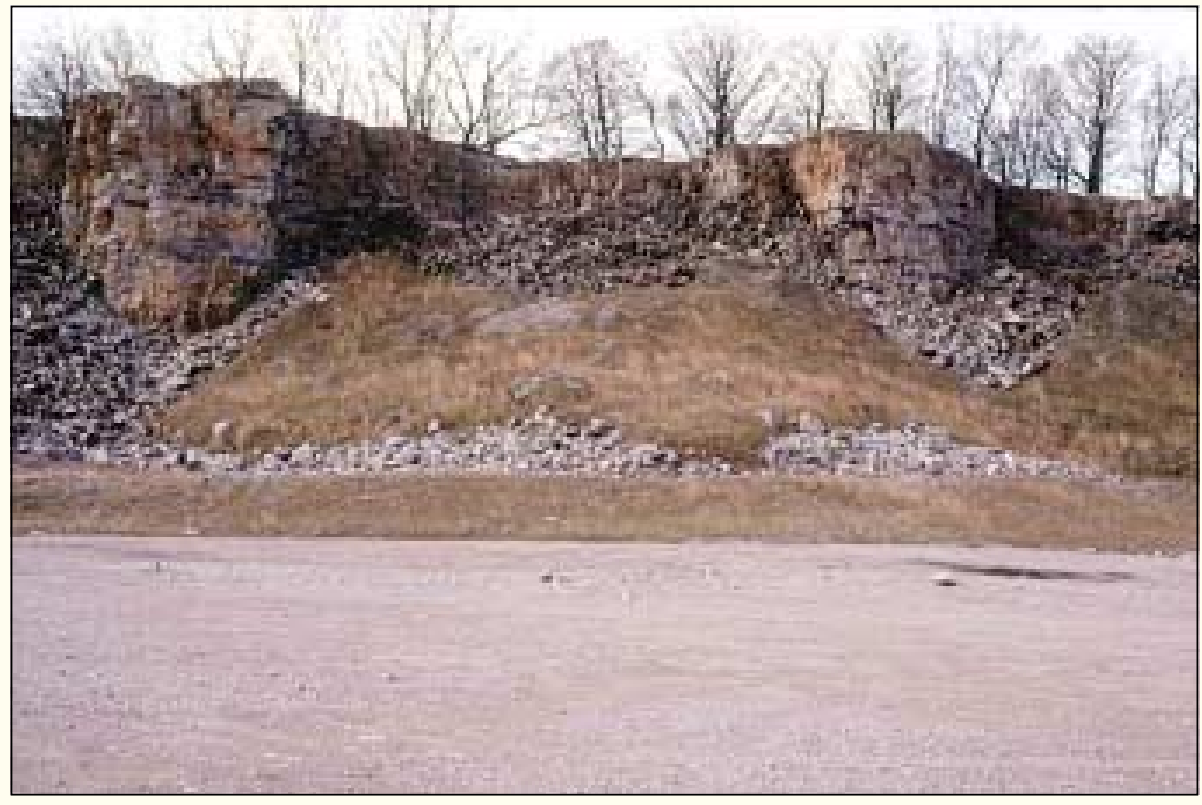

Figure 24 Face of limestone quarry after restoration blasting and habitat reclamation. (Photograph courtesyJ ohn Gunn.) 


\section{Case Studies}

There are numerous causes of environmental damage in karst, many that do not relate to quarrying. These case studies are primarily those directly related to quarrying or engineering activities, such as drilling and blasting, that are used by a number of activities, including quarrying. Units of measurements in case studies are as reported by the original authors.

Blasting - A sinkhole collapse occurred in 1983 while blasting for new highway construction near Erwin in Unicoi County, Tennessee (Newton and Tanner, 1987).

Blasting - A number of rural residents near Oxford, Alabama, reported recurring problems in turbidity of water from their individual water-supply wells and, occasionally, decreases in yield. Many residents associated the problems with blasting operations in a local rock quarry. Research identified no relationship between blasting events and the quality of water in wells. Most turbidity problems occurred during the dry period of the year (October-December) when water levels in some wells are as much as 40 feet lower than during summer months. Turbid or muddy water in some wells resulting from heavy rainfall and heavy use of ground water, particularly during extended dry periods, contributes significantly to the problem (Moore and Hughes, 1979).
Blasting- Collapse sinkholes formed at a quarry (location not given) in Paleozoic dolomitic limestone following a routine blasting event. Ground water entered through the floor of the quarry from an unsuspected conduit. The conduit connected the quarry with a karst cavern network that extended to a nearby river. Immediately following the blasting event, water flowed into the quarry at a rate of about 15,000 gpm, carrying with it eroded karstfill from the cavern. For the first few weeks, the inflow decreased in response to a rapid decline of the water table within the karst aquifer. The drainage may have led to enlargement of subsurface voids, creating a continuous connection between the river and the quarry. Subsequent river inflow to the pit further eroded fill material from the conduit and the rate of inflow increased over the next several months to over 40,000 gpm (Lolcama and others, 1999).

Drilling- Collapse at a U.S. Geological Survey test well near Keystone Heights, Florida, in 1959-60 buried a driller's helper to a depth of 30 feet and partially buried the geologist at the site. Drilling was at a depth of about 80 feet near the contact between the unconsolidated surficial material and the underlying limestone aquifers. Water level in the shallow aquifer was reportedly higher than in underlying aquifer. The well being drilled was a replacement for another recently completed and abandoned well about 12 feet away. Blasting in the abandoned well to increase yield had damaged the bottom of the casing set at depth of about 80 feet. The casing was removed prior to drilling the new well (Newton, 1987).
Drilling- Installation of wells at Westminster, Maryland, in 1940 was associated with nearby sinkhole collapse. In 1948 , the well was replaced by two new wells. During a 72-hour test, the two wells were pumped at a combined rate of 950 to $1050 \mathrm{gpm}$. A sinkhole formed near the wells and cracks reportedly formed in two nearby buildings (Newton, 1987).

Drought- As many as 40 collapses sinkholes formed in downtown Sylacauga, Alabama, during a prolonged drought in 1953-56. The largest sinkhole was as much as 30 to 40 feet in diameter and 30 to 40 feet in depth. Collapses occurred under streets, water lines, drains, and other structures including a church and football field. Sinkhole activity ceased with recovery of the water table at the end of the drought. Limited activity occurred briefly in 1981 during similar decline in water table. Some water withdrawals contributed to declines during both periods (Newton, 1987)

Freeze Protection- Collapse sinkholes formed near Pierson, Florida, during the period 1973-1979 in the cone of depression created by ground-water withdrawals. Most of the sinkholes are known to have occurred during periods of drawdown caused by irrigation for freeze protection. The remainder formed in secluded locations, but were discovered soon after periods of freeze protection pumping (Rutledge, 1982).
Mine- Many sinkholes developed coincidently with major dewatering (started 1960) of a portion of the Far West Rand mining district near Johannesburg, South Africa. Between December 1962 and February 1966, eight sinkholes greater than $50 \mathrm{~m}$ in diameter and $30 \mathrm{~m}$ in depth formed. The area is characterized by deep weathering and a thick mantel of surficial material. The depth to bedrock is as much as $400 \mathrm{~m}$ and commonly is about $100 \mathrm{~m}$. Ground water was lowered from about $100 \mathrm{~m}$ below surface to $550 \mathrm{~m}$ below surface in July of 1966. Eight large sinkholes formed after ground water was lowered to $160 \mathrm{~m}$ or more. Smaller sinkholes formed in the outer part of the cone of depression where the drawdown was between 60 and 160 $\mathrm{m}$. Several sinkholes formed where rapid seepage of water from the surface hastened the process of roof spalling and cavern enlargement. The largest of the sinkholes formed after a few days of torrential rainfall (Foose, 1967). 
Mine- Dewatering a zinc mine near Friedensville, Pennsylvania began in 1953. Active sinkhole collapse occurred in an area of large ground-water withdrawals. Records indicate that 128 sinkholes formed around the dewatering site during period 1953-57. Twenty-five new sinkholes occurred from October 1970 to January 1971. The number of sinkholes occurring during the intervening 13 years was not inventoried. The water table in lowland areas prior to withdrawals was generally at a depth of less than 30 feet. Depth to top of bedrock exceeds 30 feet in numerous areas. Rates of withdrawal between 1953 and 1977 varied between 10 and 30 million gallons per day. The cone of depression in 1967 exceeded $4 \mathrm{mi}^{2}$ in area (Metsger, 1979).

Multiple Causes - Collapse sinkholes have been reported since the beginning of the 20th century in the Tournaisis area, southern Belgium. The sinkholes developed from reactivated paleokarsts. Intensive pumping for domestic and industrial water supply, combined with the dewatering due to deep limestone quarries, resulted in the lowering of ground-water levels. This triggered the reactivation of paleokarstic systems resulting in sinkhole collapse (Kaufmann and Quinif, 1999).
Multiple Causes - An estimated 1,000 collapses west of Calera, Alabama include sites of subsidence, fracturing, and significant piping. One collapse, the "December Giant" (fig. 23), measures $145 \mathrm{~m}$ long, $115 \mathrm{~m}$ wide, and $50 \mathrm{~m}$ deep (LaMoreaux and Warren, 1973). The area was dewatered by wells, quarries, and an underground mine. The cone of depression in October 1973 was about $10 \mathrm{mi}^{2}\left(26 \mathrm{~km}^{2}\right)$ in area. Pumpage at that time exceeded 14,000 gallons per minute (883 liters per second). Significant sinkhole development began about 1964. The greatest hazards in this ural area were collapses beneath highways and major gas pipelines. Sinkholes in part of the area were still active in 1981 (Newton, 1976, 1987; Warren, 1976).

Multiple Causes - More than 150 sinkholes, depressions, and related features formed in and adjacent to the proposed right-of-way of Interstate Highway 459 near the community of Greenwood in Bessemer, Alabama. Sinkhole collapse began about 1950 and continued through March 1972. A general lowering of the water table occurred during the early 1950 's, or the preceding decade de to large withdrawals of ground water from more than 1,070 wells (1,500 gpm) and deep mines (9,500 gpm), compounded with a prolonged drought during the 1950's (Newton and others, 1973).
Quamy and underground miningQuarry and mine dewatering extended to within 1.5 miles $(2 \mathrm{~km})$ of Farmington, Missouri. Collapses were recorded at least 30 years prior to quarrying and mining and have continued for 10 years subsequent to the completion of mining activities. Although deep mines exist in areas subject to catastrophic collapse in Missouri, and continuous dewatering is required for mining, only minor surface effects have been noted (Williams and Vineyard, 1976).

\section{Quany and underground quarny} Hershey, Pa. - A series events in surface and underground quarrying near Hershey, Pennsylvania, between 1946 and 1953 altered ground-water levels over an area of $10 \mathrm{mi}$. About 100 new sinkholes formed within the area where there was a drastic lowering of the water table. Recovery of water levels to nearly normal conditions in 1950 was accompanied by a cessation of sinkhole development (Foose, 1953, 1969).
A blast of August 1946, Hershey Pa. - Blast in the hanging wall of the underground quarry near Hershey, $\mathrm{Pa}$. exposed a 6-inch-wide solution channel about 275 or 375 feet below the surface. Water flowed at 8,000 to $10,000 \mathrm{gpm}$, flooding the quarry in one day. Near-by wells dried up, ground-water seepage into a nearby quarry ceased, Derry Spring $1 \frac{1}{2}$ miles to the southwest dried up on second day, and water in two nearby wells at the Hershey Chocolate Corporation (11/2 miles northeast) rapidly declined. After many months the opening was sealed. Adjacent wells had water in them again, and flow at spring and water levels in corporate wells were restored (Foose, 1953, 1969).

Pumping Test of August 1948, Hershey, Pa. - From August 30 to September 4, 1948, an average of 5,500 gpm was pumped from the underground quarry near Hershey, Pa. as a test preliminary to permanent installation of pumps for deeper quarry operations. The water level was maintained at about 200 feet below the quarry floor. On September 2 the newly drilled Derry Spring well $1 \frac{1}{2}$ miles southwest (yield of $2100 \mathrm{gpm}$ ) dried up; water level fell from an elevation of $355 \mathrm{ft}$ to $313 \mathrm{ft}$, which was below the pump intake. On September 8 , water level began to rise, and within a couple of days normal pumping operations resumed (Foose, 1953, 1969). 
Increased pumping during May 1949 Hershey, Pa. - The quarry operation near Hershey, $\mathrm{Pa}$. inaugurated its new pumping program at about 6,500 gpm normal discharge from pumps with the intake at 340 ft. below the land surface. Derry Spring well dried up. Spring Creek dried up.

Many wells throughout the valley went dry. During the second month of the new pumping program, sinkholes began to form in the valley of Spring Creek. The size of the sinkholes ranged from 1 to $20 \mathrm{ft}$ in diameter and 2 to $10 \mathrm{ft}$ deep. Nearly 100 sinkholes

formed. More new sinkholes formed during the late summer of 1949 than had previously existed in the areas. During February and March of 1950, grouting in the underground quarry reduced flow into the quarry (flow had reached 8,000 gpm). Springs began to flow again, wells could be pumped, and Spring Creek began to flow. In 1953, the quarry was allowed to flood and became a water storage reservoir Sinkhole formation ceased after dewatering stopped and the water table had recovered (Foose, 1969).

Quarny - In 1950, a quarry at Pelham, Alabama, was in its early stages of development and sinkholes were not actively occurring. As the excavation progressed, it became necessary to dewater. In 1959, 11 open collapses were observable on aerial photographs and by 196734 open collapses were observable. The total distance of sinkhole migration was about 0.4 mile. At some time prior to October 1967, the quarry was abandoned and ground-water pumping stopped, along with sinkhole formation (Newton, 1976).
Quarny- More than 18 sinkhole collapses occurred along a planned highway corridor near Castle Hayne, North Carolina in 1980-81. These sinkholes were under the pavement of an existing road and in or adjacent to its right-of-way near a dewatered quarry. Four sinkholes were triggered by torrential rains in August 1981 (Newton, 1987).

Quany - In August and September 1994, seven sinkholes up to $5 \mathrm{~m}$ in diameter and $3 \mathrm{~m}$ deep developed at a residential property adjacent to a limestone quarry in Craven County, North Carolina. The quarry operates about $600 \mathrm{~m}$ southeast of the sinkholes and pumps water at a rate of 38 million liters per day. Water levels in wells on the perimeter of the quarry site have declined by as much as 5 meters below pre-pumping conditions. Large changes in hydraulic head were observed in monitoring wells at the quarry as the active pit was developed across the quarry site. The collapse of the sinkholes concurrent with large changes in water levels at the quarry suggests that head changes in the limestone aquifer may have been a triggering mechanism for sinkhole collapse (Strum, 1999).
Quarny- In about 1986, a limestone quarry in the Valley and Ridge Province in the southeastern United States began expansion by deepening the quarry to a new level about $60 \mathrm{~m}$ (200 ft) below the original water table. Extensive dewatering triggered sinkhole development in a nearby town and along a local railroad track. The ground-water surface was depressed in and around the quarry and appeared to affect the ground-water flow regime in and around the quarry and town. Ground-water levels were lowered 18 to $24 \mathrm{~m}(60$ to $80 \mathrm{ft})$ at a distance of about $0.8 \mathrm{~km}$ (one half mile) from the quarry. Collapse sinkholes began to develop around the quarry, occurring as much as $1.6 \mathrm{~km}$ (one mile) from the quarry. A perennial stream was captured by a sinkhole, a sinkhole drained a local wastewater treatment pond, and sinkholes and ground subsidence began to threaten the local railroad track. The summer of 1987 was a drought year for the region, and the likely impact of the drought on sinkhole development in the area was investigated. The investigation concluded that quarry dewatering related to quarry expansion was the primary cause of the sinkholes and subsidence that occurred around the town that year. A few years after the expansion, quarry operations ceased and the quarry naturally filled with water. The writers did not document any further sinkhole or subsidence activity since that time (Kath and others, 1995).
Quamy - Artificial drawdown is the probable cause of a sinkhole problem at Railton in northwestern Tasmania where limestone is excavated from a deep quarry on the floor of a broad valley beneath about $20 \mathrm{~m}$ of overburden. Prior to quarrying there was little evidence of sinkholes. Local anecdotes suggest minor sinkhole problems arose during the early years of the operation. A new bench was developed in the quarry during the early-mid 1980's, deepening the quarry by $15-20 \mathrm{~m}$, and sinkhole collapses increased. The sinkholes appeared to occur within a cone of ground-water depression around the quarry. The town sewage main was ruptured by one sinkhole. A nearby abandoned water-filled quarry drained rapidly. Other sinkholes appeared in pasture close to the quarry and in the backyards of at least two village dwellings. Exposures in the quarry reveal that the limestone surface beneath the overburden consists of pinnacles with a relief of $10-$ $15 \mathrm{~m}$. At least two small caves and one major spring were encountered at depth in the quarry. Artificial lowering of the ground-water table due to the quarrying together with differential settlement of the overburden between the limestone pinnacles was reported as the most likely cause of the problem. Inadequate drainage of runoff from the roofs of houses and outbuildings contributed to at least one collapse (Kiernan, 1989). 
Quarny - Numerous sinkholes and sites of subsidence developed in a borrow pit area near Andrew Johnson Highway west of Morristown, Tennessee. The borrow pit was active as early as April 1976. Most sinkholes occurred between 1983 and 1986. The site exhibits three distinct levels of excavating with sinkholes occurring on all levels. Ten sinkholes occurred on the lower level, two sinkholes on the middle level, and one sinkhole on the upper level. The number of sinkholes occurring on each level was correlative with amounts of drainage received by each. Three additional sinkholes occurred across a road adjacent to the borrow pit, and collapses in the road have reportedly occurred on more than one occasion (Newton and Tanner, 1987).

Quamies - Ground-water withdrawals from two quarries in the Jamestown, South Carolina area resulted in 42 sites of subsidence and collapse in 1976-78. Collapses range in size from less than $1 \mathrm{ft}$ to over $24 \mathrm{ft}$ in diameter. Most dramatic collapses occur within 5,000 $\mathrm{ft}$ of, the point of largest ground water withdrawal. About 20 feet of unconsolidated sands and clays overlie the cavernous limestone that was being quarried. Pumpage was estimated to periodically be in excess of 36 million gallons per day, causing a water level decline of over 35 feet. Water levels in wells over 1.5 miles from the center of pumping have been affected. Blasting has caused "muddying" of water (Spigner, 1978).
Quamies-Ground-water withdrawal from two deep quarries in Birmingham, Alabama, resulted in two overlapping cones of depressions, with apexes being at quarries. More than 200 sinkholes formed in an area of less than $0.5 \mathrm{mi}^{2}$ during a period of about 8 years. The formation of many of the sinkholes coincided with periods of heavy rain.

Movement of water to one quarry was verified by dye tests. Estimated total average discharge from both quarries exceeds $1.0 \mathrm{mgd}$. Withdrawals

from other sources were not identified (Newton and Hyde, 1971).

\section{Refierences}

Adamczyk, A.F., Motyka, J acek, Wilk, Zbigniew, and Witczak, Stanislaw, 1988, Mine drainage of a karstic aquifer and the related protection problems - Okusz Mining District, Poland: Proceedings if the IAH 21st Congress, Guilin, China, Geologic Publishing House, Bejing, China, pp. 1097-1104.

Aley, T.J ., Williams, J .H., and Massello, J .W., 1972, Groundwater contamination and sinkhole collapse induced by leaky impoundments in soluble rock terrain: Missouri Geological Survey Engineering Geology Series 5, 32p.

Arbogast, B.F., Knepper, D.H., J r., and Langer, W.H., 2000, The human factor in mining reclamation: U.S. Geological Survey Gircular 1191, 28p.

Assad, F.A., and J ordan, H., 1994, Karst terranes and environmental aspects: Environmental Geology, v. 23, pp. 228- 237.
ASTM, 1998, Standard terminology relating to dimension stone, American Society of Testing and Materials Designation C 119-98: American Society of Testing and Materials Annual Book of ASTM Standards, v. 04.07, pp. 6-9.

ASTM, 2000, Standard terminology relating to concrete and concrete aggregates, American Society of Testing and Materials Designation C 125-00: American Society of Testing and Materials Annual Book of ASTM Standards, v. 04.02, pp. 60-63.

Barksdale, R.D., ed., 1991, The aggregate handlbook: National Stone Association, $717 p$

Bates, R.L, and J ackson, J .A., eds., 1987, Glossary of Geology: American Geological Institute, $788 \mathrm{p}$.

Beck, B.F., ed., 1984, Sinkholes - Their geology, engineering and environmental impact: Proceedings of the First

Multidisciplinary Conference on Sinkholes, A.A. Balkema, $429 p$.

Beck, B.F., ed., 1989, Engineering and environmental impacts of sinkholes and karst: Proceedings of the Third Multidisciplinary Conference on Sinkholes and the Engineering and Environmental Impacts of Karst, A.A. Balkema, $384 \mathrm{p}$.

Beck, B.F., ed., 1993, Applied karst geology: Proceedings of the Fourth Multidisciplinary Conference on Sinkholes and the Environmental Impacts of Karst, A.A. Balkema, $295 p$.

Beck, B.F., ed., 1999, Sinkholes and the Engineering and Environmental Impacts of Karst: Engineering Geology, v. 52, nos. 1-2, $152 \mathrm{p}$.
Beck, B.F., and Pearson, F.M., eds., 1995, Karst geohazards - Engineering and environmental problems in karst terrane: Proceedings of the Fifth Multidisciplinary Conference on Sinkholes and the Environmental Impacts of Karst, A.A Balkema, $581 \mathrm{p}$.

Beck, B.F., and Stephenson, J .B., eds. 1997, The engineering geology and hydrogeology of karst terranes:

Proceedings of the Sixth Multidisciplinary Conference on Sinkholes and the

Engineering and Environmental Impacts of Karst, A.A. Balkema, $516 \mathrm{p}$.

Beck, B.F., and Wilson, W.L, eds., 1987, Karst hydrology: Engineering and environmental applications: Proceedings of the Second Multidisciplinary Conference on Sinkholes and the Environmental Impacts of Karst, A.A. Balkema, $467 p$

Beck, B.F., Pettit, A.J ., and Herring, J .G., eds., 1999, Hydrogeology and engineering geology of sinkholes and karst: Proceedings of the Seventh Multidisciplinary Conference on Sinkholes and the Engineering and Environmental Impacts of Karst, A.A. Balkema, 478 p.

Bell, F.G., 1992, Open excavation in rock masses, in, Bell, F.G., ed., Engineering in rock masses: Buterworth, Heinemann, Oxford, England, p. 400-422

Berger, P.R., Ford, W.C., Graham E.K., Long, J .F., J r., Rohrs, D.M., West, J .R., and Willard, R.B., 1991, Environmental and community concerns, in Barksdale, R.D., The Aggregate Handbook: National Stone Association, p. 5-1- 5-59.

Bobrowsky, P.T., ed., 1998, Aggregate resources - A global perspective: A.A. Balkema, Rotterdam Netherlands, $470 \mathrm{p}$. 
Bowles, Oliver, 1939, The Stone Industries: McGraw Hill Book Company, 519p.

Crawford, N.C., 1986, Karst hydrological problems associated with urban development - ground water contamination, hazardous fumes, sinkhole flooding and sinkhole collapse in the Bowling Green area, Kentucky: Field Trip Guide Book, Centre for Cave and Karst Studies, Western Kentucky University, $86 \mathrm{p}$

Cujíc,J ., 1893, Das karstphanomen: Versucheiner monphologischen Monographie, Geographische Abhandlungen herausgegeben von A Pench. Bd., V.H, 3 Wien.

Dodge, E.D., 1984, Les characteristiques hydrogeoloqigues des aquifers kartisques du Causse Comtal (Aveyron, France): Hydrogeologie-Geologie de l'ingenieur, v. 3, pp. 241-252

Dolley, T.P., 1999, Crushed stone: U.S. Geological Survey Minerals Yearbook, pp. 73.1-73.11

Drew, David, 1999, Chapter 1 - Introduction, in Drew, David, and Hötz, Heinz, eds. Karst hydrology and human activities Impacts, consequences and implications, A.A. Balkema, pp. 3-12

Drew, David, and Hötz, Heinz, eds., 1999 Karst hydrology and human activities Impacts, consequences and implications, A.A. Balkema, $322 \mathrm{p}$.

Drysdale, R., Pierotti, L, and Baldacci, F., 2001, Suspended sediments in karst spring waters near Massa (Tuscany). Italy: Environmental Geology, v. 40, pp. 1037-1050.
Edwards, A.J ., Hobbs, S.L, and Smart, P.L 1991, Effects of quarry dewatering on a karstified limestone aquifer; a case study from the Mendip Hills, England, in Proceedings of the Third Conference on Hydrogeology, ecology, monitoring and management of groundwater in karst terranes, National Water Well Association, pp. 77-91.

Ekmekçi, M., 1993, Impact of quarries on karst groundwater systems, in Günay, G., J ohnson, A.I., and Back, W., eds, Hydrogeological processes in karst terranes: Proceedings of the Antalya Symposiumand Field Seminar, October 1990, IAHS Publication no. 207, p. 3-6

Fletcher, J .L., and Busnel, R.G., 1978, Effects of noise on wildlife: Academic Press, New York.

Foose, R.M., 1953, Ground-water behavior in the Hershey Valley, Pennsylvania: Geological Society of America Bulletin, $v$. 64, pp. 623-646.

Foose, R.M., 1967, Sinkhole formation by groundwater withdrawal; Far West Rand, South Africa: Science, v. 157, pp. 1045-1048

Foose, R.M., 1969, Mine dewatering and recharge in carbonate rocks near Hershey, Pennsylvania, in Kiersch, G.A., Cleaves, A.B., Adams, W.M., Pincus, H.J ., and Ferguson, H.F., eds., Legal aspects of geology in engineering practice: Geological Society of America, Engineering Geology Case Histories no. 7, pp. 46-60
Foose, R.M., and Humphreville, J . A., 1979 Engineering geological approaches to foundations in the karst terrain of the Hershey Valley: Bulletin of the Association of Engineering Geologists, v. 16, no. 3, pp. 355-381

Ford, D.C., ed., 1993, Environmental change in karst areas: Environmental Geology, v. 21 , no. 3, pp. 107-200.

Ford, D.C., and Williams, P.W., 1989, Karst geomorphology and hydrology: UnwinHyman, London, $601 \mathrm{p}$.

Fraser, Hannah, and Grapes, Tim 1998, Impact of quarry dewatering on a water dependent conservation site, in Van Brahana, J ohn, Eckstein, Yoram Ongley, K. Schneider, Robert, and Moore, J .E. eds., Gambling with groundwater Physical, chemical, and biological aspects of aquifer-systemrelations: American Institute of Hydrology, pp. 469-474.

Gagen, Peter, and Gunn, J ohn, 1987, A geomorphological approach to restoration blasting in limestone quarries, in Beck, B.F., and Wilson, W.L, eds., Karst hydrology: Engineering and environmenta applications: Proceedings of the Second Multidisciplinary Conference on Sinkholes and the Environmental Impacts of Karst, A.A. Balkema, pp. 457-461

Gary, M.K., 1999, Maryland's zone of dewatering influence law for limestone quarries, in Beck, B.F., Pettit, A.J ., and Herring, J .G., eds., Hydrogeology and engineering geology of sinkholes and karst - 1999: Proceedings of the Seventh Multidisciplinary Conference on Sinkholes and the Engineering and Environmental Impacts of Karst, A.A. Balkema, pp. $273-277$
Gillieson, David, and Houshold, Ian, 1999. Chapter 6.3-Rehabilitation of the Lune River Quarry, Tasmanian Wilderness World Heritage Area, Australia: in Drew, David, and Hötd, Heinz, eds. Karst hydrology and human activities - Impacts, consequences and implications, A.A. Balkema, pp. 201-205.

Gunn, J ohn, 1986, A conceptual model for conduit flow dominated karst aquifers, inGünay, Gültekïn, andJ ohnson, A.I., eds. Karst water resources: IAHS Publication 161, pp. 587-596.

Gunn, J ohn, 1993, The geomorphic impacts of limestone quarrying, in Williams, P.W., ed. Karst terrains - Environmental changes and human impact: Catena Supplement 25 , Catena Verlag, Cremlingen, pp. 187-197.

Gunn, J ohn, and Bailey, Debra., 1993, Limestone quarrying and quarry reclamation in Britain: Environmental Geology, v. 21, pp. 167-172

Gunn, J ohn, Bailey, Debra, and Handley, J ohn, 1997, The reclamation of limestone quarries using landformreplication: Department of Geographical \& Environmental Sciences, University of Huddersfield, Queensgate, Huddersfield, U.K., $176 \mathrm{p}$.

Gunn, J ohn, and Gagen, Peter, 1987, Limestone quarrying and sinkhole development in the English Peak District in Beck. B.F., and Wilson, W.L, eds., Karst hydrology: Engineering and environmental applications: Proceedings of the Second Multidisciplinary Conference on Sinkholes and the Environmental Impacts of Karst A.A. Balkema, pp. 121-125. 
Gunn, J ohn, and Hobbs, S.L, 1999, Chapter 6.2 Limestone quarrying: hydrogeological impacts, consequences, implications: in Drew, David, and Hötz, Heinz, eds.: Karst hydrology and human activities Impacts, consequences and implications, A.A. Balkema, pp. 192-201.

Hess, J .W., and Slattery, LD., 1999, Chapter 6.1 Overview of extractive industries impact,in Drew, David, and Hötz, Heinz, eds.: Karst hydrology and human activities - Impacts, consequences and implications, A.A. Balkema, pp. 187-192.

Hobbs, S.L, and Gunn, J ohn, 1998, The hydrogeological effect of quarrying karstified limestone: options for protection and mitigation: Quarterly J ournal of Engineering Geology, v. 31, pp. 147-157.

Howard, Bob, and Cameron, Ian, 1998 Dust control: Best Practice Environmental Management in Mining, Environment Australia, $73 \mathrm{p}$.

J ennings, J .N., 1985, Karst geomorphology: Bell and Bain Ltd., Glasgow, 293 p.

Kath, R.L, McClean, A.T., Sullivan, W.R., and Humphries, R.W., 1995, Engineering impacts of karst: Three engineering case studies in Cambrian and Ordovician carbonates of the Valley and Ridge Province, in Beck, B.F., and Pearson, F.M eds., Karst geohazards - Engineering and environmental problems in karst terrane: Proceedings of the Fifth Multidisciplinary Conference on Sinkholes and the Environmental Impacts of Karst, A.A. Balkema, pp. 469-457.

Kaufmann, Oliver, and Quinif, Yves, 1999, Cover-collapse sinkholes in the "Tournaisis" area, southern Belgium Engineering Geology, v. 52, nos. 1\&2, pp. 15-22.
Kelk, B., 1992, Natural resources in the geological environment, in Lumsden, G.I. 1992, ed. Geology and the environment in Western Europe: Oxford University Press, New York, p. 34- 138

Kestner, M., 1994, Developing a dust control plan: Stone Review v.10, no. 1, p. 22-23.

Kiernan, Kevin, 1989, Sinkhole hazards in Tasmania, in Beck, B.F., ed., Engineering and environmental impacts of sinkholes and karst: Proceedings of the Third Multidisciplinary Conference on Sinkholes and the Engineering and Environmental Impacts of Karst, A.A. Balkema, pp. 123-128.

Kochanov, W.E, 1999, Sinkholes in Pennsylvania: Pennsylvania Geological Sunvey, $4^{\text {th }}$ Series, Educational Series $11,33 \mathrm{p}$.

Kolm K.E., 1996, Conceptualization and characterization of ground-water systems using geoscientific information systems, in May, J . and Kolm K. E., eds, 1996, Special Issue: Advanced Techniques for Solving Groundwater Contaminant Problems: Engineering Geology, Vol. 42; Nos. 2- 3, Elsevier Publishers, p. 111 - 118

Kresic, Neven, Papic, Petar, and Golubovic Radosav, 1992, Elements of groundwater protection in a karst area: Environmental geology Water Science, v. 20., no. 3, pp. 157-164.

LaMoreaux, P.E., 1997, Legal aspects of karst and insurability, in Günay, Gültekïn and J ohnson, A.I., eds., Karst waters \& environmental impacts: Proceedings of the $5^{\text {th }}$ International Symposiumand Field Seminar on Karst Waters and Environmental Impacts, Antalya, Turkey, A.A. Balkema, pp. 11-17.
LaMoreaux, P.E., Powell, W.J ., and LeGrand, H.E., 1997, Environmental and legal aspects of karst areas: Environmental Geology, $v$. 29 , no. $1 / 2$, pp. $23-36$

LaMoreaux, P.E., and Newton, J .G., 1986 Catastrophic subsidence: An environmental hazard, Shelby County, Alabama: Environmental Geology Water Science, v. 8, no. 1/2, p. 25-40

LaMoreaux, P.E., and Warren, W.M., 1973, Sinkhole: Geotimes, v. 18, no. 3, p. 15.

Langer, W.H., 2001, Environmental impacts of mining natural aggregate, in Bon R.L., Riordan, R.F., Tripp, B.T., and Krukowski, S.T., eds., Proceedings of the 35th Forumon the Geology of Industrial Minerals-The Intermountain West Forum Utah Geological Survey Miscellaneous Publication 01-2, p. 127-138

Langer, W.H., in press, Environmenta Risk Analysis and Aggregate Mining, in Proceedings of the $37^{\text {th }}$ Forum on the Geology of Industrial Minerals, 2001 British Columbia Ministry of Energy and Mines.

Langer, W.H., and Kolm K.E., 2001 Hierarchical systems analysis of potential environmental impacts of aggregate mining: Society for Mining, Metallurgy, and Exploration, Inc., Annual Meeting, 2001 Preprint No. 01-103, 10p.

Lolcama, J .L, Cohen, H.A., and Tonkin, M.J ., 1999, Deep karst conduits, flooding and sinkholes: Lessons for the aggregates industry, in Beck, B.F., Pettit, A.J ., and Herring, J .G., Hydrogeology and engineering geology of sinkholes and karst - 1999: Proceedings of the Seventh Multidisciplinary Conference on Sinkholes and the Engineering and Environmental Impacts of Karst, A.A. Balkema, pp. 51-55.
Lüttig, G.W, 1994, Rational management of the geo-environment - A view in favour of "geobased" planning - with special reference to aggregate resources, in Lüttig, G.W., ed., Aggregates -- Raw materials' giant: Report on the 2nd International Aggregate Symposium Erlangen, $346 \mathrm{p}$.

Martin, A.D., 1995, Maryland Route 31 sinkhole, in Beck, B.F., and Pearson, F.M., eds., Karst geohazards - Engineering and environmental problems in karst terrane: Proceedings of the Fifth Multidisciplinary Conference on Sinkholes and the Environmental Impacts of Karst, A.A. Balkema, pp. 331-334.

Metsger, R.W., 1979, Mining problems in a karst valley - Technical and social: Bulletin of the Association of Engineering Geologists, v. 16, n. 3, pp. 427-447.

Meyers, P.B., J r., and Perlow, M., J r., 1984, Development, occurrence, and triggering mechanisms of sinkholes in the carbonate rocks of the Lehigh Valley, eastern Pennsylvania,in Beck, B.F., ed., 1984, Sinkholes - Their geology, engineering and environmental impact: Proceedings of the First Multidisciplinary Conference on Sinkholes, A.A. Balkema, pp. 11-15.

Moore, J .D., and Hughes, T.H., 1979, Effect of quarry blasting on ground-water quality in a limestone terrane in Calhoun County, Alabama: Water Resources Research Institute Bulletin 38, Auburn University, $72 \mathrm{p}$

Moore, A.B., and Richards, A.J ., 1999, Blast vibration assessment for planning and control: Quarry, v.7, no. 4, p. 28-32. 
National Academy of Sciences, 1980, Surface mining of non-coal minerals - Appendix I - Sand and gravel mining, and quarrying and blasting for crushed stone and other construction minerals: National Academy of Sciences, Washington, D.C., 91 p.

Newton, J .G., 1976, Induced sinkholes A continuing problemalong Alabama highways, in International Association of Hydrologic Sciences, Land Subsidence Symposium Proceedings of the Second International Symposiumon Land Subsidence held at Anaheim California, IAHS-AISH Publication no. 121, pp. 453-463

Newton, J .G., 1984a, Review of induced sinkhole development, in Beck, B.F., ed., Sinkholes: Their geology, engineering and environmental impact: Proceedings of the First Multidisciplinary Conference on Sinkholes, A.A. Balkema, pp. 3-9.

Newton, J .G., 1984b, Sinkholes resulting fromground-water withdrawals in carbonate terranes-an ovenview, in Holzer, T.L, ed., Man-induced land subsidence: Geological Society of America, Reviews in Engineering Geology, v. 6, pp. 195-202

Newton, J .G., 1984c, Case History No. 9.11. Alabama, U.S.A., in Poland, J .F., ed. Guidebook to studies of land subsidence due to ground-water withdrawal: UNESCO, pp. 245-251

Newton, J .G., 1986, Natural and induced sinkhole development in the eastern United States, inJ ohnson, A.I., Carbognin, Laura, and Ubertini, L, eds., Land Subsidence: Proceedings of the Third International Symposiumon Land Subsidence held in Venice, Italy, IAHS Publication No. 151, pp 549-564.
Newton, J .G., 1987, Development of sinkholes resulting fromman's activities in the Eastern United States; U.S. Geological Survey Circular 968, 54p.

Newton, J .G., Copeland, C.W., and Scarbough, LW., 1973, Sinkhole problemalong proposed route of Interstate Highway 459 near Greenwood, Alabama: Alabama Geological Survey Grcular 83, $53 \mathrm{p}$.

Newton, J .G., and Hyde, LW., 1971, Sinkhole problemin and near Roberts Industrial Subdivision, Birmingham Alabama - A reconnaissance: Geological Survey of Alabama Gircular 68, 42p.

Newton, J .G., and Tanner, J .M., 1987, Case histories of induced sinkholes in the eastern United States, in Beck, B.F., and Wilson, W.L., eds., Karst hydrology: Engineering and environmental applications: Proceedings of the Second Multidisciplinary Conference on Sinkholes and the Environmental Impacts of Karst, A.A. Balkema, pp. 15-23.

Primel, Louis, and Tourenq, Claude, 2000, eds. Aggregates: Balkema, $590 \mathrm{p}$.

Prokopovich, N.P., 1985, Development of karst sinkholes and fluctuations of aquifer levels, in Günay, Gültekïn, and J ohnson, A.l., eds. Karst water resources: IAHS Publication 161, pp. 387-397.

Quinlan, J .F., 1986, Legal aspects of sinkhole development and flooding in karst terranes - 1 Review and synthesis; Environmental Geology and Water Sciences, v. 8, nos. 1/2 pp. 41-61.

Ritter, D.F., Kochel, R.C., and Miller, J .R., 1995, Process geomorphology - Third edition: WmC. Brown Publishers, Chicago, 546p.
Rutledge, A.T., 1982, Hydrology of Floridian aquifer in northwest Volusia County, Florida: U.S. Geological Survey WaterResources Investigations Open-File Report 82-108, 116 p.

Sauro, U., 1993, Human impact on the karst of the Venetian Fore-Alps, Italy: Environmental Geology, v. 21, pp. 115-121

Sedam A.C., Eberts, S.M., and Bair, E.S., 1988 Ground-water levels, water quality, and potential effects of toxic-substance spills or cessation of quarry dewatering near a municipal ground-water supply, southern Franklin County, Ohio: U.S. Geological Survey Water-Resources Investigations report 88-4138, $93 \mathrm{p}$.

Sinclair, W.C., 1982, Sinkhole development resulting fromgroundwater withdrawal in the Tampa area, Florida: U.S. Geologica Survey Water Resources Investigation 81-50, 19p.

Sinclair, W.C., and Stewart, J .W., 1985 Sinkhole type, development, and distribution in Florida: Florida Bureau of Geology, Map series No. 110.

Smart, P.L, Edwards, A.J ., and Hobbs, S.L, 1991, Heterogeneity in carbonate aquifers: Effects of scale, fissuration, lithology and karstification, in Proceedings of the Third Conference on Hydrogeology, ecology, monitoring and management of groundwater in karst terranes: National Water Well Association, pp. 373-388.

Smart, P.L, and Friedrich, H., 1986, Water movement and storage in the unsaturated zone of a maturely karstified carbonate aquifer, Mendip Hills, England, in Proceedings Environmental Problems in Karst Terranes and Their Solutions Conference: National Water Well association, 59-87.
Smith, M.R., and Collis, L, eds., 2001, Aggregates -- Sand, gravel and crushed rock aggregates for construction purposes, $3^{\text {td }}$ Edition: Geological Society of Engineering Geology Special Publication No. 17, London, The Geological Society, 339p.

Sowers, G.F., 1976, Mechanisms of subsidence due to underground openings, in, National Academy of Science Subsidence over mines and caverns, moisture and frost actions, and classification: Transportation Research Record 612, pp. 2-8

Spigner, B.C., 1978, Land surface collapse and ground-water problems in the J amestown area, Berkley County, South Carolina: South Carolina Water Resources Commission Open-File Report 78-1, 99p.

Stanton, W., 1966, The impact of quarrying on the Mendip Hills, Somerset: Proceedings of the University of Bristol Speleological Society, v. 11, p. 5462

Stanton, W., 1990, Hard limestone - Too valuable to quarry: Minerals Planning, $\mathrm{V}$. 43, pp. 3-9.

Stringfield, V.T., and Rapp, J .R., 1976, Land subsidence resulting from withdrawal of ground water in carbonate rocks, in International Association of Hydrologic Sciences, Land Subsidence Symposium Proceedings of the Second Internation Symposiumon Land Subsidence held at Anaheim California, IAHS-AISH Publication no. 121 pp.447-452 
Strum Stuart, 1999, Topographic and hydrogeologic controls on sinkhole formation associated with quarry dewatering,in Beck, B.F., Pettit, A.J ., and Herring, J .G., Hydrogeology and engineering geology of sinkholes and karst - 1999. Proceedings of the Seventh Multidisciplinary Conference on Sinkholes and the Engineering and Environmental Impacts of Karst, A.A. Balkema, pp. 63- 66 .

Sweeting, M.M., 1981, Karst Geomorphology: Benchmark Papers in Geology / 59, Hutchinson Ross Publishing Company, Stroudsburg, Pennsylvania, $427 \mathrm{p}$.

Tepordei, V.V., 1999, Crushed stone: U.S. Geological Survey Minerals Yearbook, pp. 72.1-72.32

Thorp, M.J.W., and Brook, G.A., 1984, Application of double Fourier series analysis to ground subsidence susceptibility mapping in covered karst terrain, in Beck, B.F., ed., Sinkholes: Their geology, engineering and environmental impact: Proceedings of the First Multidisciplinary Conference on Sinkholes, A.A. Balkema, pp. 197-20?

Ursic, K.A., Kenkel, N.C., and Larson, D.W., 1997, Revegetation dynamics of cliff face in abandoned limestone quarries: J ourna of Applied Ecology, v. 34, pp. 289-303.

Urushibara-Yoshino, K., 2000, Newsletter on annotated bibliography, No. 8: International Geographical Union, Department of Geography, Hosei University, Tokyo, 71 p.

Veni, George, and DuChene, Harvey, eds., 2001, Living with karst: American Geological Institute Environmental Awareness Series, 4, 64p.
Vermeulen, J aap, and Whitten, Tony, 1999, Biodiversity and cultural property in the management of limestone resources: World Bank, Washington, D.C., $120 \mathrm{p}$.

Waltham A.C., 1989, Ground subsidence: Blackie \& Son Limited, London, $195 \mathrm{p}$

Warren, W.M., 1976, Sinkhole occurrence in westem Shelby County, Alabama: Geological Sunvey of Alabama Gircular 101, 45p.

Warren, W.M., and Wielchowsky, C.C., 1973, Aerial remote sensing of carbonate terranes in Shelby County, Alabama: Ground Water, v. 11, no. 6, p. 14-26.

White, W.B., and White, E.L, 1995, Thresholds for soil transport and the long term stability of sinkholes, in Beck, B.F., and Pearson, F.M., eds., Karst geohazards Engineering and environmental problems in karst terrane: Proceedings of the Fifth Multidisciplinary Conference on Sinkholes and the Environmental Impacts of Karst A.A. Balkema, pp.73-78.

White, W.B., Culver, D.C., Herman, J .S., Kane, T.C., and Mylroie, J .E., 1995, Karst lands: American Scientist, v. 83, pp. 450-459.

Williams, J .H., and Vineyard, J .D., 1976, geologic indicators of subsidence and collapse in karst terrain in Missouri, in, National Academy of Science, Subsidence over mines and caverns, moisture and frost actions, and classification: Transportation Research Record 612, pp. 31-37.

Williams, P.W., ed., 1993, Karst terrains -

Environmental changes and human impact: Catena Supplement 25, Catena Verlag, Cremlingen, 268p.
Wilson, W.L, and Beck, B.F., 1992 Hydrogeologic factors affecting new sinkhole development in the Orlando area, Florida: Ground Water, v. 30, no. 6, pp. 918-930

Yuan, Daoxian, 1987, Karst hydrology: Engineering and environmental applications, in Beck, B.F., and Wilson, W.L, eds., Proceedings of the Second Multidisciplinary Conference on Sinkholes and the Environmental Impacts of Karst A.A. Balkema, pp.1-11. 